\title{
Crops that feed the world 6. Past successes and future challenges to the role played by maize in global food security
}

\author{
Bekele Shiferaw • Boddupalli M. Prasanna • \\ Jonathan Hellin • Marianne Bänziger
}

Received: 7 June 2011 / Accepted: 4 July 2011 / Published online: 23 August 2011

(C) The Author(s) 2011. This article is published with open access at Springerlink.com

\begin{abstract}
Maize is one of the most important food crops in the world and, together with rice and wheat, provides at least $30 \%$ of the food calories to more than 4.5 billion people in 94 developing countries. In parts of Africa and Mesoamerica, maize alone contributes over $20 \%$ of food calories. Maize is also a key ingredient in animal feed and is used extensively in industrial products, including the production of biofuels. Increasing demand and production shortfalls in global maize supplies have worsened market volatility and contributed to surging global maize prices. Climatic variability and change, and the consequent rise in abiotic and biotic stresses, further confound the problem. Unless concerted and vigorous measures are taken to address these challenges and accelerate yield growth, the outcome will be hunger and food insecurity for millions of poor consumers. We review the research challenges of ensuring global food security in maize, particularly in the context of climate change. The paper summarizes the importance of maize for food, nutrition and livelihood security and details the historical productivity of maize, consumption patterns and future trends. We show how crop breeding to overcome biotic and abiotic stresses will play a key role in meeting future maize demand. Attention needs to be directed at the generation of high yielding, stresstolerant and widely-adapted maize varieties through judicious combination of conventional and molecular breeding approaches. The use of improved germplasm per se will
\end{abstract}

B. Shiferaw $(\bowtie) \cdot$ B. M. Prasanna

International Maize and Wheat Improvement Center (CIMMYT), Nairobi, Kenya

e-mail: b.shiferaw@cgiar.org

J. Hellin · M. Bänziger

International Maize and Wheat Improvement Center (CIMMYT),

El Batán, Mexico not, however, be enough to raise yields and enhance adaptation to climate change, and will need to be complemented by improved crop and agronomic practices. Faced with emasculated state extension provision and imperfect markets, new extension approaches and institutional innovations are required that enhance farmers' access to information, seeds, other inputs, finance and output markets. Over the long-term, large public and private sector investment and sustained political commitment and policy support for technology generation and delivery are needed to overcome hunger, raise the incomes of smallholder farmers and meet the challenges of growing demand for maize at the global level.

Keywords Maize - Productivity growth - Demand . Food security. Crop breeding · Climate change · Policy

\section{Introduction}

Together with rice and wheat, maize provides at least $30 \%$ of the food calories to more than 4.5 billion people in 94 developing countries. They include 900 million poor consumers for whom maize is the preferred staple. Maize is currently produced on nearly 100 million hectares in 125 developing countries and is among the three most widely grown crops in 75 of those countries (FAOSTAT, 2010). About $67 \%$ of the total maize production in the developing world comes from low and lower middle income countries; hence, maize plays an important role in the livelihoods of millions of poor farmers. By 2020, the world will have around 7.7 billion people and by 2050 the figure will be approximately 9.3 billion. Between now and 2050, the demand for maize in the developing world will double (Rosegrant et al., 2009). 
The nature of the demand for maize is also changing. Maize is an important food crop but over the past decade, its demand as livestock feed has grown tremendously. This has largely been driven by rapid economic growth in highly populated regions in Asia, the Middle East and Latin America leading to increased demand for poultry and livestock products from more affluent consumers (Delgado, 2003). Maize grain is a key ingredient in animal feed and this added demand has driven up prices of maize grain and made it less affordable for poor consumers in several regions of the world. The maize feed market is growing especially in countries such as China and India, where economic growth is enabling many to afford milk, eggs and meat. Rapid development in these countries is also driving up demand for maize as an industrial raw material while maize is a key ingredient in the bioethanol program in the USA.

Production shortfalls in global maize supplies and increasing input prices have grave consequences for developing countries. Along with prices of other commodities, especially wheat, maize prices have increased by $43 \%$ since 2008 and are projected to increase in the future in response to increasing demand and constraints for expanding supplies. Such increases will impose great hardship on the poor, as the food price surge of 2008 and early 2011 have made abundantly clear. In addition, lagging domestic production will place a huge and politically risky burden on developing country economies, driving up their maize imports from about the $7 \%$ of today's demand to $24 \%$ in 2050 , a proportion that will be priced at around USD 30 billion (Rosegrant et al., 2009). Unless vigorous measures are taken to accelerate the growth of yield, the outcome will be less affordable food for millions of poor maize consumers.

Farmers, governments, researchers and input suppliers have been responding to the expanding demand for maize. During 2003-08, maize production increased annually by $6.0 \%$ in Asia, $5.0 \%$ in Latin America, and $2.3 \%$ in subSaharan Africa (FAOSTAT 2010). Nonetheless, the increases fell short of those needed to prevent price hikes in 2008. Part of the response to increasing demand has involved bringing new land into cultivation, increasing maize area in Asia and Latin America by 3.5\% annually (FAOSTAT 2010, referring to data from 2003-08). Area expansion, however, is not a sustainable option and often comes with an environmental cost in terms of increased land degradation. At the current rate of area expansion, increases in future production will come at the cost of crop diversity and forest conservation. The major challenge for the future is achieving significant growth in food production without compromising public health, environmental quality, and sustainability of farming systems (Tilman et al., 2002).

Although crop breeding alone is not a panacea, by developing high-yielding crop varieties it is likely to play a critical role in meeting the need for increasing food production even though huge challenges remain (Delmer, 2005). Maize production (as well as other cereals) doubled in the past 40 years due to increased yields resulting from the use of improved crop varieties, along with greater inputs of fertilizer, water and pesticides (Evenson and Gollin, 2003). The difficulty of meeting the need for increased food production is exacerbated by climate change. Spatial analyses and crop modelling studies have consistently predicted a decline in maize yields for many developing countries in the tropics. Using CIMMYT data from more than 20,000 historical maize trials in Africa, combined with daily weather data, Lobell et al. (2011) estimated that each degree day spent above $30^{\circ} \mathrm{C}$ reduced the final yield by $1 \%$ under optimal rainfed conditions and by $1.7 \%$ under drought conditions. For Africa particularly, the impacts will be highly variable, with Southern Africa likely to be affected most, while some regions (such as the East African highlands) may see improved conditions for maize production. The challenge will be to provide maize farmers with the means to respond both to the threats and opportunities posed by climate change.

The combined challenges of increasing demand, continuing poverty and malnutrition, natural resource depletion and climate change will require the world to double the productivity and dramatically increase the sustainability and resilience of maize-based farming systems. This requirement can only be met through a concerted engagement of farming communities, international and national researchers, policy makers, the private sector, and many other development partners which intrinsically involves target communities and national governments in designing appropriate and pro-poor solutions. This review article is, hence, a synthesis of a series of debates, discussions and action plans on how maize can continue to contribute to food and livelihood security of poor producers and consumers at the global level and especially in the developing regions.

The article is structured as follows: in Section 2 we present the role of maize for food, nutrition and livelihood security-looking at the importance of maize in the growing demand for food, feed and other uses at the regional and global levels. Section 3 highlights the historical productivity of maize, consumption patterns and future trends. Section 4 looks at the constraints to productivity growth in terms of biotic and abiotic stresses and the challenges that these pose to maize breeders. The vulnerability of maize-based farming systems to climate change are addressed in Section 5. Section 6 presents the future technology options to overcome the effects of major abiotic and biotic constraints. Section 7 reviews the policy and institutional barriers to the adoption of maize technologies. In the conclusions (Section 8), we identify key lessons and action points for policy makers, researchers and development practitioners. 


\section{Role of maize for global food security}

Maize is grown over a wider range of altitudes and latitudes than any other food crop, under temperatures ranging from cool to very hot, on wet to semi-arid lands, and in many different types of soils. The global area for maize (average for 2008-2010) is about 150 million ha. The corresponding average annual production was over 750 million metric tons. This is, by far, larger than the production of the two other major staple cereals (wheat and rice) (Fig. 1). During the same period, maize represented an average of $27 \%$ of cereal area, $34 \%$ of cereal production and $8 \%$ of the value of all primary crop production. This includes estimated area and production of green maize, which is highly valued as the harvest approaches at the end of the hungriest season. The regional distribution of area and production is given in Table 1.

Maize is an important source of food and nutritional security for millions of people in the developing world, especially in Africa and Latin America. The role of maize for human consumption, expressed in terms of the share of calories from all staple cereals, varies significantly across regions. This ranges from $61 \%$ in Mesoamerica, $45 \%$ in Eastern and Southern Africa (ESA), 29\% in the Andean region, ${ }^{1} 21 \%$ in West and Central Africa (WCA), to $4 \%$ in South Asia. The contribution of maize as a source of proteins from all the cereal staples is very similar to its contribution of calories (Fig. 2). Its use as a source of food accounts for $25 \%$ and $15 \%$ of the total maize demand in the developing countries and globally, respectively. In subSaharan Africa, maize is mainly a food crop accounting for $73 \%$ and $64 \%$ of the total demand in ESA and WCA. In South Asia 46\% is used as food mainly for poor households who cannot afford other staples such as rice and wheat. The demand for food is also high in Mesoamerica (44\%), North Africa (39\%) and the Andean region (36\%) as well as South East Asia (29\%; see Fig. 3). This makes maize particularly important to the poor in many developing regions of Africa, Latin America and Asia as a means of overcoming hunger and improving food security. Its high yields (relative to other cereals) make maize particularly attractive to famers in areas with land scarcity and high population pressure.

Maize production has spread widely from its origins in Mesoamerica into new areas beyond the USA and Canada, especially during the second millennium. As it was introduced to new cultures and new agro-ecologies, new varieties were selected to meet dietary preferences better and new uses were developed with adaptation to new biophysical environments. Despite its relatively recent

\footnotetext{
${ }^{1}$ The Andean region includes Bolivia, Colombia, Ecuador, Guyana, Peru, Suriname and Venezuela.
}

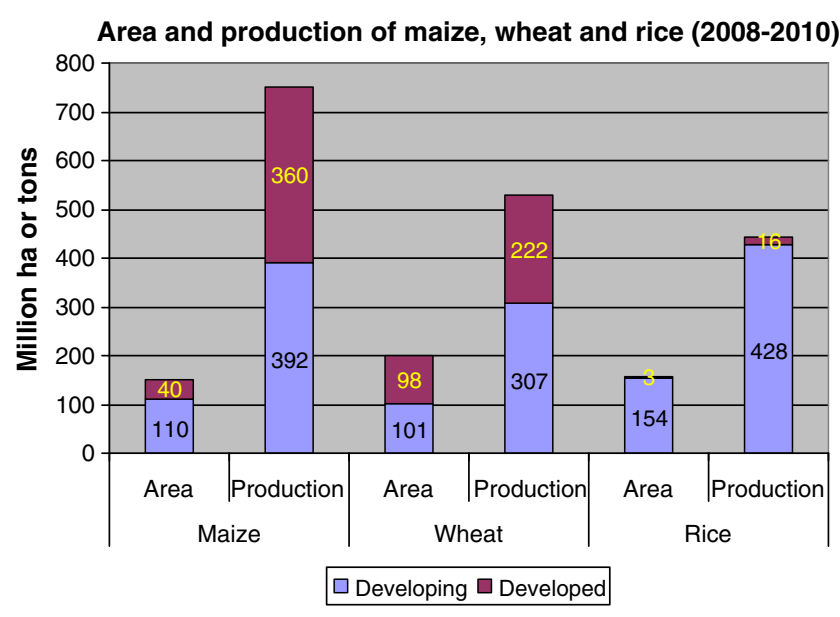

Fig. 1 Global area and production of maize and other major cereals. Source: Computed by authors based on USDA online database

introduction into Africa, it has become one of the most important staples in the region. By the 1930s, maize had become important in smallholder agriculture in Africa both as a subsistence and as a cash crop. The construction of infrastructure, and especially railways, further encouraged the expansion of smallholder maize cultivation. The nearly complete change in the diets of tens of millions of Africans from traditional sorghum and millet to maize in less than two generations represents an almost unprecedented transformation in food production and consumption patterns (Byerlee and Heisey, 1997). Societies in sub-Saharan Africa also share two attributes with their counterparts in Mexico and Central America. First, with the exception of pockets in West Africa, Africans south of the Sahara demonstrate an overwhelming preference for white maize. As an estimated $96 \%$ of world trade in maize is yellow, this preference has implications for exchange of germplasm and for trade. ${ }^{2}$ Second, in contrast with other major maize-producing regions of the world, farmers in both sub-Saharan Africa and Mesoamerica generally grow maize as a food crop rather than as an industrial crop-although they often sell it for cash.

Maize currently covers 25 million ha in sub-Saharan Africa, largely in smallholder systems that produce 38 million metric tons, primarily for food (Smale et al., 2011). An additional 2.8 million ha is grown in South Africa, mostly in large-scale commercial production, much of it for animal feed. The highest amounts of maize consumed are found in Southern Africa at $85 \mathrm{~kg} / \mathrm{capita} /$ year as compared to 27 in East Africa and 25 in WCA. In Lesotho, Malawi, South Africa, Zambia and Zimbabwe, average consumption

\footnotetext{
${ }^{2}$ Provided by Paul W. Heisey, based on 2008/9 data from USDA/FAS and the US Federal Grains Inspection Service. According to these data, in some recent years, the US exported a significant amount of white maize to Mexico, but these amounts have never reached more than $15 \%$ of total US maize exports to Mexico.
} 
Table 1 Maize area, production, yield and consumption across maize growing regions

\begin{tabular}{|c|c|c|c|c|c|c|c|c|}
\hline Region & $\begin{array}{l}\text { Annual } \\
\text { average area } \\
\text { (million ha) } \\
\text { 2008-2010 }\end{array}$ & $\begin{array}{l}\text { Annual average } \\
\text { production } \\
\text { (million MT) } \\
2008-2010\end{array}$ & $\begin{array}{l}\text { Annual } \\
\text { average yield } \\
\text { (MT/ha) } \\
\text { 2008-2010 }\end{array}$ & $\begin{array}{l}\text { Area } \\
\text { growth rate } \\
(\% / \text { year }) \\
2001-2010\end{array}$ & $\begin{array}{l}\text { Production } \\
\text { growth rate } \\
\text { ( \%/year) } \\
2001-2010\end{array}$ & $\begin{array}{l}\text { Yield } \\
\text { growth rate } \\
\text { (\%/year) } \\
2001-2010\end{array}$ & $\begin{array}{l}\text { Average food } \\
\text { supply quantity } \\
\text { (kg/capita/yr)- } \\
\text { 2005-2007 }\end{array}$ & $\begin{array}{l}\text { Average share } \\
\text { in grand total } \\
\text { calories intake } \\
2005-07(\%)\end{array}$ \\
\hline $\begin{array}{l}\text { Eastern and Southern } \\
\text { Africa with } \\
\text { South Africa }\end{array}$ & 18.04 & 34.38 & 1.9 & 1.83 & 4.83 & 2.77 & 79.07 & 22.44 \\
\hline $\begin{array}{l}\text { Eastern and Southern } \\
\text { Africa without } \\
\text { South Africa }\end{array}$ & 14.99 & 21.55 & 1.44 & 2.41 & 4.51 & 1.95 & 76.91 & 19.00 \\
\hline $\begin{array}{l}\text { Western and Central } \\
\text { Africa }\end{array}$ & 11.12 & 17.4 & 1.56 & 3.26 & 6.28 & 2.80 & 26.16 & 9.18 \\
\hline $\begin{array}{l}\text { West Asia and North } \\
\text { Africa }\end{array}$ & 2.17 & 13.63 & 6.29 & 1.40 & 4.14 & 2.78 & 22.73 & 6.93 \\
\hline South Asia & 10.53 & 25.11 & 2.38 & 2.46 & 6.41 & 3.56 & 6.08 & 2.31 \\
\hline $\begin{array}{l}\text { Southeast Asia and } \\
\text { Pacific }\end{array}$ & 8.26 & 25.92 & 3.14 & 1.26 & 4.60 & 3.26 & 15.87 & 4.72 \\
\hline East Asia & 31.4 & 165.51 & 5.27 & 3.13 & 4.81 & 1.64 & 8.17 & 2.06 \\
\hline $\begin{array}{l}\text { Mexico, Central } \\
\text { America and } \\
\text { the Caribbean }\end{array}$ & 9.26 & 26.84 & 2.89 & 0.56 & 3.42 & 2.66 & 61.72 & 26.15 \\
\hline Other Latin America & 19.13 & 83.24 & 4.36 & 0.60 & 3.87 & 3.14 & 26.56 & 10.96 \\
\hline $\begin{array}{l}\text { Eastern Europe and } \\
\text { Former Soviet Union }\end{array}$ & 6.5 & 29.13 & 4.49 & 3.98 & 9.68 & 5.78 & 6.19 & 1.87 \\
\hline $\begin{array}{l}\text { North America and } \\
\text { other developed } \\
\text { countries }\end{array}$ & 33.57 & 330.89 & 9.86 & 1.45 & 2.98 & 1.51 & 23.51 & 2.09 \\
\hline Developing Countries & 109.9 & 392.01 & 3.57 & 1.87 & 4.26 & 2.34 & 10.52 & 5.90 \\
\hline World & 149.97 & 752.04 & 5.01 & 1.78 & 3.64 & 1.81 & 16.60 & 4.95 \\
\hline
\end{tabular}

Sources: Computed by authors based on United States Department of Agriculture (USDA) online database. (production data) and FAOSTAT online database (food supply and consumption data).

MT= Metric tons

is over $100 \mathrm{~kg} / \mathrm{capita} /$ year. These amounts represent more than $50 \%$ of total calories in Lesotho, Malawi and Zambia, $43 \%$ in Zimbabwe, and $31 \%$ in South Africa. The dependence on maize in many countries in the region is a concern for food and nutritional security, especially when other supplements for dietary diversity are limited. Maize
Calories from cereals (\%)

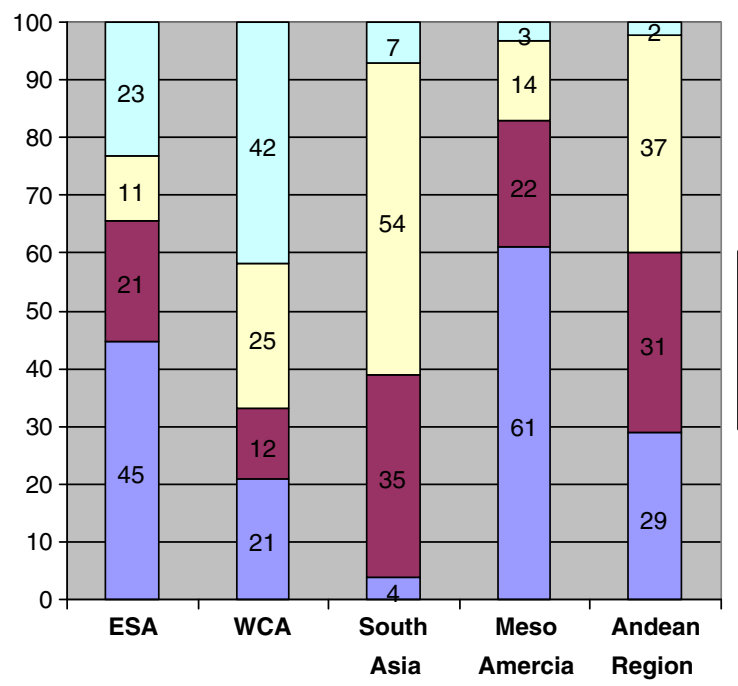

Proteins from all cereals (\%)

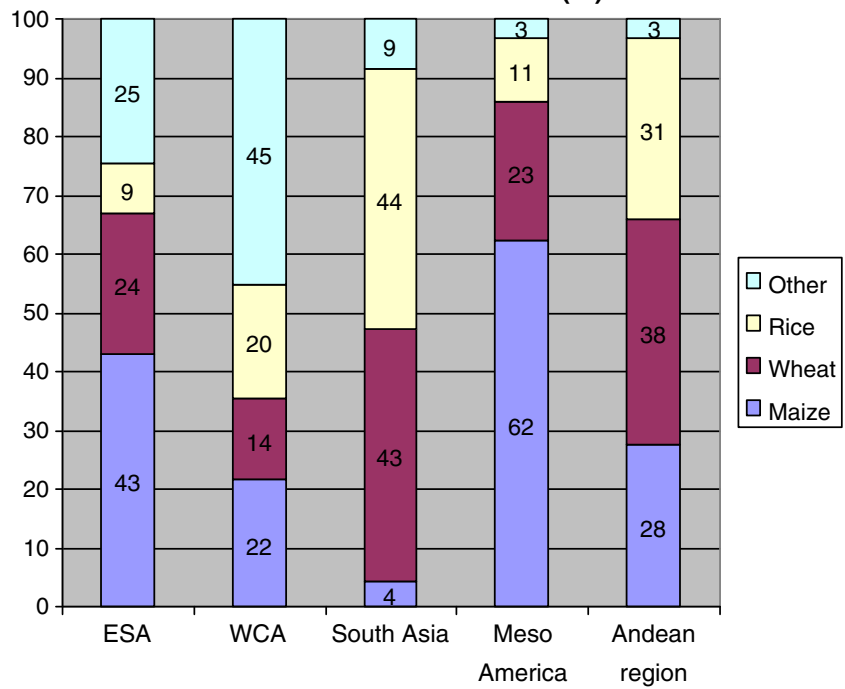

Fig. 2 Role of maize as source of calories and proteins in the developing countries. Source: Computed by authors based on FAOSTAT online database 


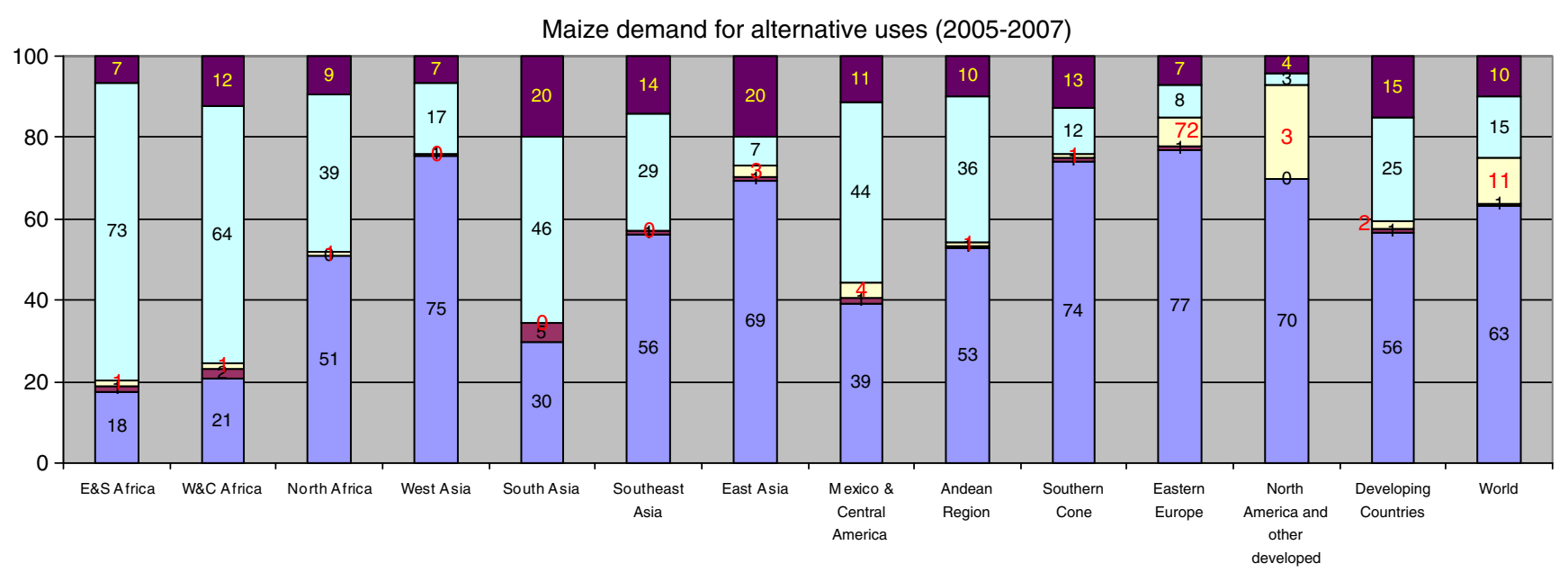

$\square$ Feed $\square$ Seed $\square$ Processing $\square$ Food $\square$ Other use

Fig. 3 Diversification of demand for maize in different regions. Source: Computed by authors based on FAOSTAT online database

provides vitamins $\mathrm{A}$ and $\mathrm{E}$ but lacks the lower B vitamins that characterize other grains such as sorghum or wheat; maize is low in usable protein and its leucine blocks the human body's absorption of niacin, a vitamin whose absence causes protein deficiency (McCann, 2005). Decades of efforts by breeders at CIMMYT have led to the development of "Quality Protein Maize" (QPM) with enhanced nutritional value, especially through higher levels of lysine and tryptophan in the endosperm and better amino acid balance. In Ethiopia, Tanzania and Uganda, randomized trials showed significantly improved height and weight of children consuming such varietiesparticularly in Southern Ethiopia, where the population relies heavily on maize (Gunaratna et al., 2008).

Maize is not just used for human consumption. Figure 3 shows that maize demand is significantly diversified from its use as a source of food to livestock feed, industrial processing, seed and other alternative uses. At the global level $63 \%$ of the maize demand is for livestock feed while in the developing countries this currently stands at around $56 \%$. These aggregate figures obscure significant variation in alternative uses at the country level (e.g. food vs. feed) across the developing and the developed world. In the high income countries, $70 \%$ of maize is used as feed and only $3 \%$ for direct human consumption. By contrast, in subSaharan Africa outside of South Africa, more than twothirds of maize is used as food and only about $18-20 \%$ as animal feed.

The industrial demand for maize is mainly related to its growing use in the bio-energy sector. Investment in maizebased bioethanol is booming. Around 50 developing countries have established targets for blending ethanol with gasoline. Maize in particular is a primary feedstock for ethanol production in the huge US 'corn ethanol' program.
Given the importance of maize for human/animal consumption and for biofuel production, it is also important to analyze the potential trade-offs around using maize to produce ethanol. With large-scale production of bioethanol using maize grain in first-generation conversion technologies, food prices and levels of child malnutrition would increase significantly, especially in sub-Saharan Africa and South Asia (e.g. see Headey and Fan 2010). Recent market trends suggest that the two drivers of bioethanol expansion (high oil prices and policies for domestic energy security) are unlikely to weaken during the coming decades, and could even intensify. Thus the boom in the USA may only be a foretaste of what may unfold in the coming decades.

Maize is also an important component of feed for the meat industry, especially in Asia where maize consumption has soared, driven by the growing demand for maize as poultry and pig feed. Total meat consumption in seven major Asian countries (China, India, Indonesia, Nepal, Thailand, Philippines, Vietnam), mostly pork and poultry meat, rose from 20 million metric tons in 1980 to 77 million metric tons in 2000, (Wada et al., 2008). In the poultry industry maize accounts for most of the energy in the feed ration for broilers: broiler rations, on average, contain $60-65 \%$ maize, $28-30 \%$ soybean meal, and 2-3\% oil. Overall maize use for feed in the seven major Asian countries has more than tripled from 29 million metric tons in 1980 to 109 million metric tons in 2000 (Wada et al., 2008). World-wide demand for maize as livestock feed is growing at $6 \%$ per year, and is projected to be a major component of future demand.

With increasing diversification of maize demand and utilization, global trade has become an important strategy for overcoming production shortfalls. Maize is the second most widely traded cereal after wheat. Annual exports, 
estimated at about 90 million metric tons, mainly from North America (USA), Eastern Europe (mainly Ukraine) and South America (mainly Argentina and Brazil) meet the growing demand for maize imports in Mexico, North Africa, East Asia, and West Asia and South East Asia among the developing countries and Japan and Canada among the high income economies (Fig. 4).

Most of these imports are related to the growing use of maize as livestock feed. The exports from the US account for slightly more than half of the annual traded volumes while the Southern cone of Latin America accounts for about one-third of the total amount. An important issue to note is that sub-Saharan Africa is largely self-sufficient as a region with South Africa meeting the production shortfalls in the other growing countries. However, this inter-regional trade in Africa is beginning to suffer as many countries have put restrictions on imports of genetically modified (GMO) maize grown in South Africa. Data on the exact share of non-transgenic and transgenic maize is not available but most of the maize produced in South Africa is reported as genetically modified. This certainly has created a major market uncertainty for both importers and South African producers and exporters and may significantly change the structure of maize trade in the region.

\section{Historical productivity growth, consumption patterns and future trends}

Maize area and production at the global level have shown dramatic changes over the past 50 years. Between 1961 and
2010 , the global maize area increased by $50 \%$, that is from about 100 million to more than 150 million ha. Significantly, much of the area growth occurred in the developing countries where cultivated area has almost doubled from 60 million ha in 1961 to about 112 million ha in 2010 . Production and productivity has also registered a much faster growth in the developing regions. Production increased by more than five fold from about 75 million metric tons to about 405 million metric tons during the same period. In the developed economies, area has changed very little over time - 39 million ha (1961) to 41 million ha (2010). However, the production of maize has increased three-fold, indicative of an impressive growth in productivity over the 50 year period. This picture among the developed and developing countries indicates a dramatic growth in maize production at the global level - registering almost a four-fold increase from 200 million metric tons (1961) to 765 million metric tons (2010) (Fig. 5).

These figures, however, conceal significant variability among regions and countries in terms of area, yield and production responses over the past half century. For example, despite the tripling of the maize area, yield has not shown significant changes in sub-Saharan Africa. Excluding South Africa, maize yields in sub-Saharan Africa only increased by about $40 \%$ over this period (from about $0.9 \mathrm{t} / \mathrm{ha}$ to $1.5 \mathrm{t} / \mathrm{ha}$ ). Variability of yield for maize is also extremely high in this region. The area, yield and production growth rates for maize across the different regions are given in Table 1 . Over the past 10 years, the annual growth in area expansion is highest in WCA (3.26\%), East Asia (3.13\%) and Eastern Europe (3.98\%).

Average net imports of maize (M MT), 2008-2010

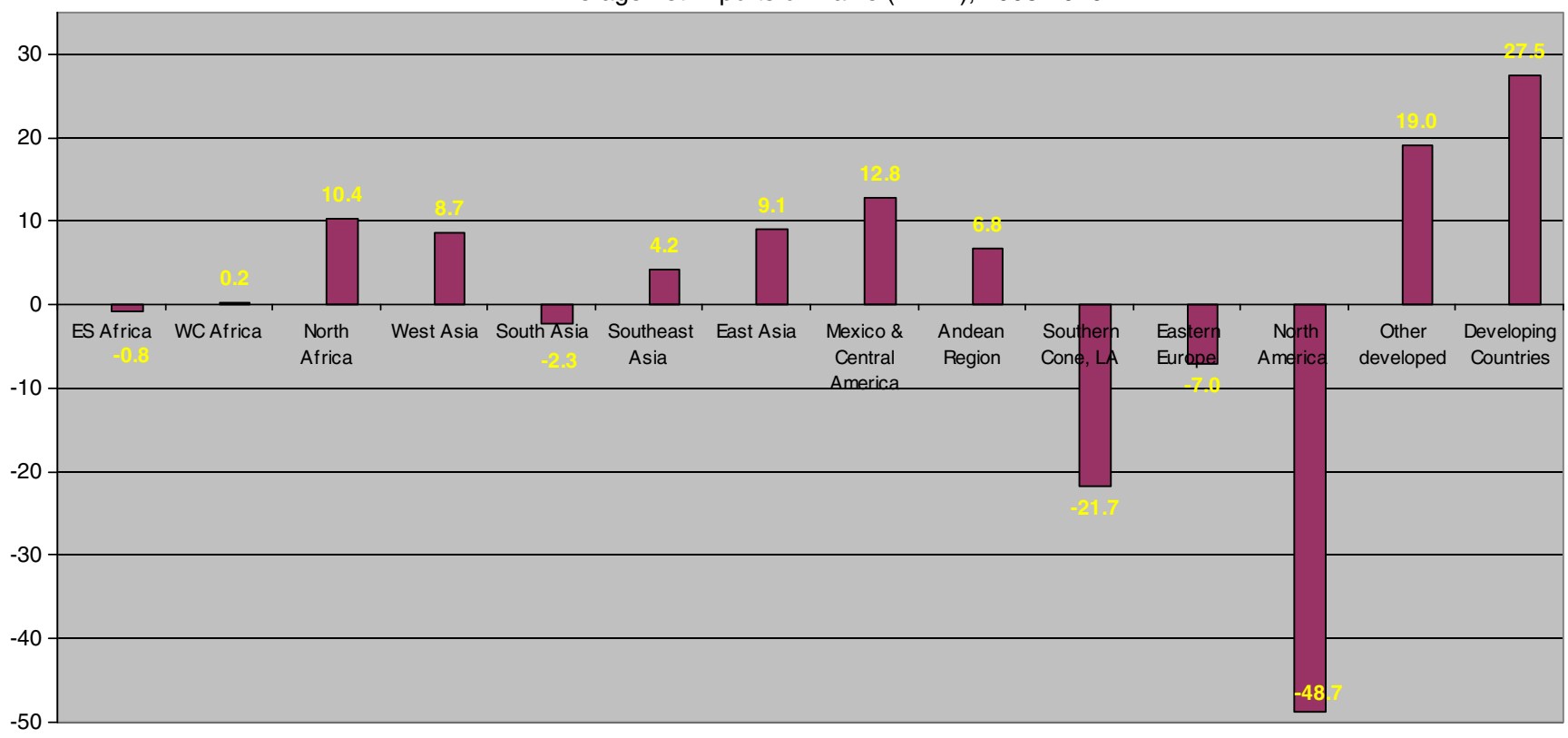

Fig. 4 Regional patterns in the net imports of maize. Source: Computed by authors based on USDA online database 

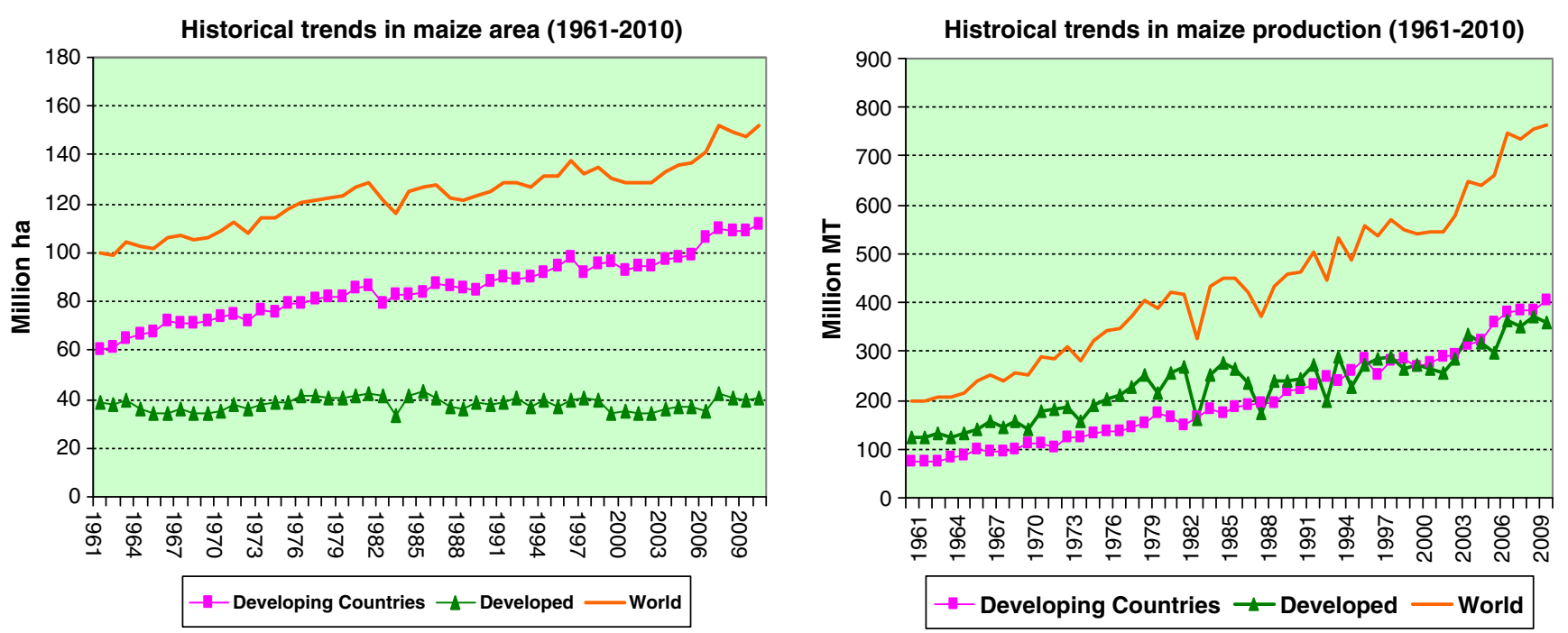

Fig. 5 Historical trends in area and production of maize (1961-2010). Source: Computed by authors based on USDA online database

The annual yield responses are highest in Eastern Europe (5.78\%), South Asia (3.56\%), South East Asia (3.26\%) and Latin America (3.14\%).

Maize is primarily grown as a rainfed crop in many developing countries including sub-Saharan Africa, Asia and Latin America. Under uncertain climatic conditions, this increases the risks associated with maize production. Depending on the climatic uncertainties, this dependence on rainfall causes the year to year variation in maize yields and production (Table 2). Although regional aggregate data still hide a lot of information on intra-regional variation across countries, the variability of production and yield (measured in terms of coefficient of variation, CV) is very high for countries in Africa, South Asia, and Latin America as well as Eastern Europe. When complemented with market risks associated with poorly integrated domestic and regional markets, small-scale maize producers often face significant challenges in smoothing consumption and income over time. Better varieties for stress tolerance and investment in water management and value chain development will help mitigate these inherent risks.

The contribution of area and yield productivity growth to the historical annual production growth (1961-2010) across the different regions is presented in Fig. 6. The annual area growth rates are negative in West Asia and Eastern Europe where maize area has declined over time. As indicated above, the historical growth in area is largest in WCA where

Table 2 Variability of production and yields of maize in different regions

\begin{tabular}{|c|c|c|c|c|}
\hline Region & $\begin{array}{l}\text { CV of production } \\
\text { (percent)1991-2000 }\end{array}$ & $\begin{array}{l}\text { CV of production } \\
\text { (percent) 2001-2010 }\end{array}$ & $\begin{array}{l}\text { CV of yield (percent) } \\
1991-2000\end{array}$ & $\begin{array}{l}\text { CV of yield (percent) } \\
2001-2010\end{array}$ \\
\hline Eastern and Southern Africa with South Africa & 18.32 & 17.33 & 14.86 & 11.28 \\
\hline Eastern and Southern Africa without South Africa & 14.75 & 18.47 & 6.81 & 10.76 \\
\hline Western and Central Africa & 5.57 & 17.03 & 4.83 & 7.16 \\
\hline West Asia and North Africa & 8.15 & 10.79 & 12.49 & 9.14 \\
\hline South Asia & 11.72 & 17.88 & 7.97 & 10.80 \\
\hline Southeast Asia and Pacific & 7.73 & 16.25 & 9.72 & 12.49 \\
\hline East Asia & 12.17 & 14.18 & 6.14 & 5.12 \\
\hline Mexico, Central America and the Caribbean & 7.03 & 8.28 & 6.93 & 7.43 \\
\hline Other Latin America & 10.94 & 16.39 & 11.38 & 10.85 \\
\hline Eastern Europe and Former Soviet Union & 33.96 & 22.14 & 18.29 & 12.41 \\
\hline North America and other developed countries & 14.06 & 12.86 & 10.14 & 7.06 \\
\hline Developing Countries & 8.84 & 13.82 & 6.08 & 7.35 \\
\hline World & 8.09 & 13.05 & 6.66 & 6.71 \\
\hline
\end{tabular}

Sources: Computed by authors based on USDA online database (production data). 
Maize area and yield growth (\%/yr), 1961-2010

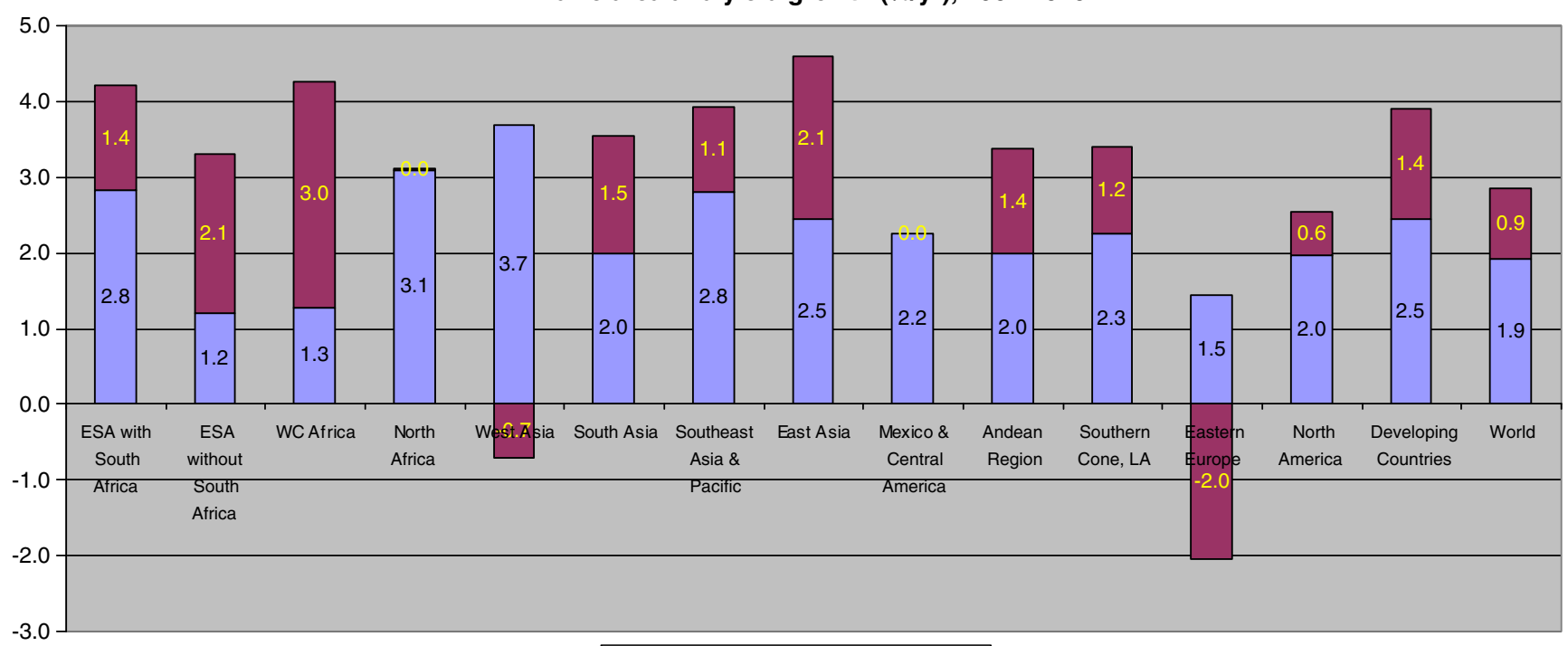

Yield growth $\square$ Area growth

Fig. 6 Historical growth rates in maize area and yields. Source: Computed by authors based on USDA online database

maize is a relatively new crop and has expanded rapidly over the last 50 years into new growing years. The area increased from about 2.6 million ha in 1961 to 11.2 million ha in 2010. Overall, East Asia (mainly China) and WCA have shown the largest annual growth rates as the sum of area and yield together, followed by ESA (including South Africa) and South East Asia.

The main driver of the dramatic growth in production and yield response at the global level is the growth in demand for maize for both food and non-food uses. It is significantly higher than for other cereals (wheat and rice)

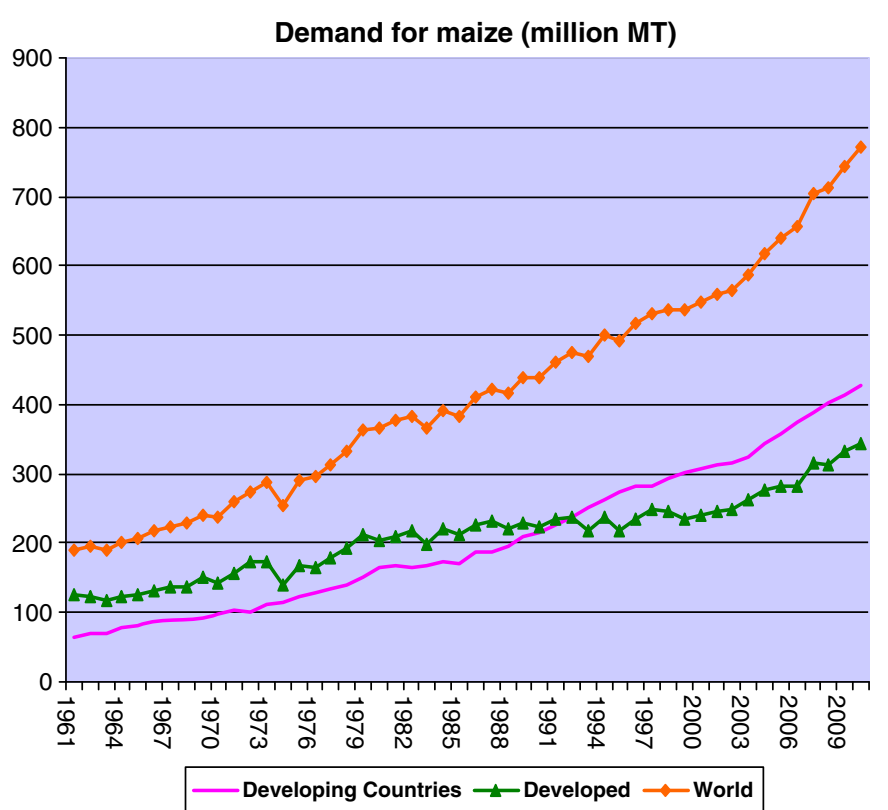

and increased by more than four fold from 189 million metric tons in 1961 to 771 million metric tons in 2010. In 2010, maize accounted for more than $40 \%$ of the global demand for the major cereals while wheat and rice accounted for $30 \%$ and $25 \%$, respectively. Much of the growth in maize demand originated from the developing regions where it has grown by more than six fold from 65 million tons to 427 million tons during the same period. Demand only grew by less than half of this rate in the high income economies (from 124 to 344 million metric tons), (Fig. 7).

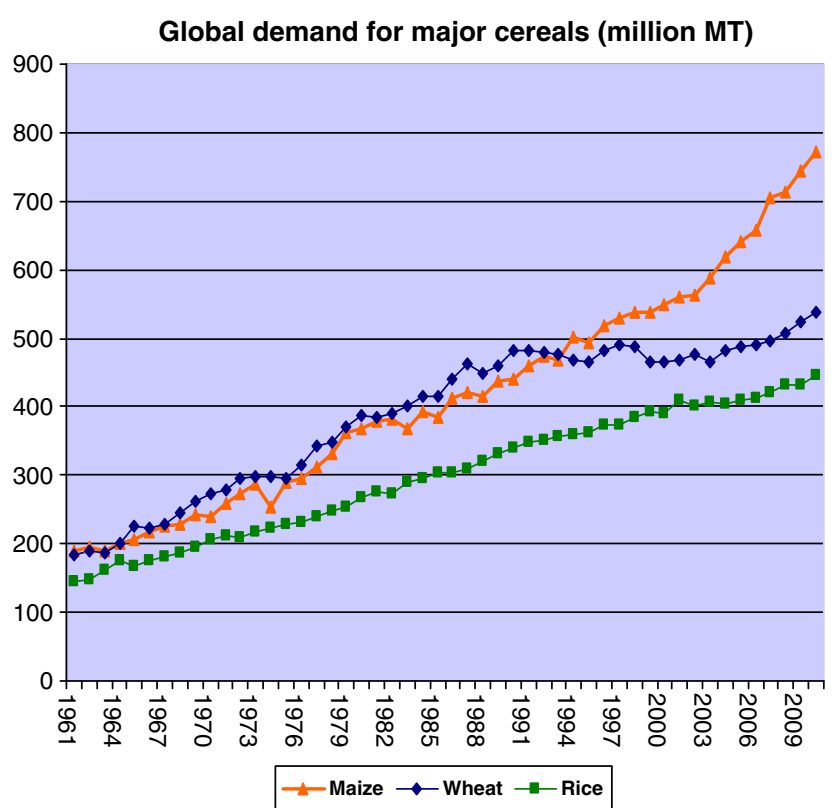

Fig. 7 Historical patterns in the demand for maize and other major cereals. Source: Computed by authors based on USDA online database 
The demand for maize in the developing countries is projected to double by 2050 . In addition, by 2025 maize will have become the crop with the highest production in the developing world (Rosegrant et al., 2009). This implies that the overall demand for maize in the developing countries will be larger than the other major cereals (rice and wheat). It is mainly driven by growth in population as well as changes in income and urbanization that induce changes in dietary patterns in the emerging economies. Worldwide meat demand is estimated to rise by more than 55\% between 1997 and 2020, with most of that increase taking place in developing countries. Asia will account for half of the increase in global cereal demand. Global demand for maize will increase by $50 \%$ from 558 million metric tons in 1995 to a projected 837 million tons in 2020 (Wada et al., 2008). Maize demand in Asia will increase by $87 \%$ from 162 million tons in 1995 to 303 million tons in 2020. Most of the extra 140 million tons of maize that will be produced in Asia between 1995 and 2020 will be fed to livestock.

At current levels of productivity growth, maize production will fall short of the accelerating demand. Unless vigorous measures are taken to accelerate productivity growth, many poor consumers in urban and rural areas in the developing world may face hunger as food prices soar and make it difficult to meet their subsistence requirements. The price effect will particularly depend on policy decisions to use maize for biofuels, the price of fuel and the size of the negative effect of climate variability and change on global and regional maize production. Under business as usual models, the outcome will be food insecurity for millions of maize consumers, continuing childhood malnutrition and loss of wellbeing for the poor, which may create social unrest and instability.

\section{Biotic and abiotic constraints to productivity growth}

Maize is the basis for food security in some of the world's poorest regions in Africa, Asia, and Latin America, yet yields are often extremely low, averaging approximately 1.5 tons per hectare-about $20 \%$ of the average yield in developed countries. Yields in low-productivity rainfed environments are severely limited by an array of factors, including abiotic and biotic stresses. Recurrent drought, low levels of fertilizer use, and low adoption of improved varieties all contribute to the low yields.

Abiotic stresses

Drought is the most important constraint to enhancing maize production and productivity in the tropical and sub- tropical regions. A decade ago, before recognition of climate change, Heisey and Edmeades (1999) estimated that in sub-Saharan Africa roughly a quarter of the 10.4 million ha of maize in the lowland tropics and $22 \%$ of the 7.6 million ha in the mid-altitude/subtropics were frequently under stress from drought. Soil fertility is probably an even more serious constraint in most maize growing environments in Africa, due to very low use of fertilizer and the demise of bush-fallow systems of soil fertility replenishment (Morris et al., 2007).

Despite these constraints, Africa has huge potential in maize production. An estimated 88 million ha of land is suited to maize that is not presently cultivated, even after excluding protected and forested areas (World Bank, 2010). This is almost three times the area currently sown and over half of the available land suited to maize production globally. Most of the potential for area expansion is in ESA, particularly Sudan, Mozambique, Angola and Tanzania (see Table 3).

Table 3 Land available that is suitable for maize expansion ${ }^{a}$

\begin{tabular}{|c|c|c|c|c|}
\hline & \multirow{2}{*}{$\begin{array}{l}\text { Current } \\
\text { maize area } \\
1000 \text { ha }\end{array}$} & \multirow{2}{*}{$\begin{array}{l}\text { Area under population } \\
\text { density }<25 \\
\text { persons } / \mathrm{km}^{2} \\
\text { Total (1000 ha) }\end{array}$} & \multicolumn{2}{|c|}{$\begin{array}{l}\text { Available land } \\
(1000 \text { ha) in } \\
\text { relation hours } \\
\text { to a market towr }\end{array}$} \\
\hline & & & $<6 \mathrm{~h}$ & $>6 \mathrm{~h}$ \\
\hline Nigeria & 3845 & 1,301 & 876 & 426 \\
\hline Tanzania & 3100 & 3,715 & 2,271 & 1,444 \\
\hline South Africa & 2799 & 1,063 & 911 & 152 \\
\hline Ethiopia & 1767 & 2,395 & 114 & 2,281 \\
\hline Zimbabwe & 1730 & 1,002 & 851 & 151 \\
\hline Kenya & 1,700 & 2,568 & 1,009 & 1,559 \\
\hline D.R. Congo & 1,484 & 2,657 & 1,185 & 1,472 \\
\hline Mozambique & 1,400 & 7,592 & 4,206 & 3,386 \\
\hline Angola & 1,115 & 4,109 & 1,030 & 3,079 \\
\hline Zambia & 664 & 5,716 & 2,383 & 3,333 \\
\hline Burkina Faso & 608 & 2,306 & 1,376 & 930 \\
\hline Guinea & 484 & 1,458 & 1,198 & 261 \\
\hline Madagascar & 250 & 6,753 & 4,654 & 2,100 \\
\hline Chad & 235 & 9,131 & 3,736 & 5,395 \\
\hline $\begin{array}{l}\text { Central African } \\
\text { Republic }\end{array}$ & 130 & 2,405 & 84 & 2,322 \\
\hline Sudan & 31 & 31,889 & 14,390 & 17,499 \\
\hline Mali & 330 & 2,358 & 1,580 & 778 \\
\hline Malawi & 1,597 & 12 & 8 & \\
\hline $\begin{array}{l}\text { Sub-Saharan } \\
\text { Africa }\end{array}$ & 22,939 & 88,430 & 41,862 & 46,572 \\
\hline World Total & 161,017 & 156,828 & 83,310 & 74,419 \\
\hline
\end{tabular}

${ }^{a}$ Non-forested land available in population density under 25 persons per squared kilometre

Source: World Bank, 2010, cited in Smale et al., 2011 
Given the rapidly growing demand for maize, which will require intensified cropping systems in the context of increasing scarcity and value of agricultural water, and likely unfavorable climate change scenarios, the value of drought tolerance in maize is certain to increase. In southern Africa, the incidence of drought during 2002-03 resulted in a food deficit of 3.3 million tons, with an estimated 14 million people at risk of starvation. In 2005-06 and again in 2009, severe droughts struck maize fields in eastern Africa, and drought regularly affects crops in the dry belts of Mexico and Central America, and parts of South and South East Asia. Farmers affected by recurrent drought tend not to invest in yieldenhancing inputs but respond instead by planting large areas to low-input maize in the hope of ensuring household food security. Stabilizing and increasing productivity in the face of recurrent drought can promote cropping diversification, better management of soil fertility, and income generation.

Nitrogen-either applied as fertilizer or from organic sources like manure or legumes-is one of the most important nutrients for plants, but small-scale maize farmers often cannot afford chemical fertilizer. African farmers, who are mainly smallholders, use, on average, less than $10 \mathrm{~kg}$ of fertilizer per hectare of crop land. Therefore, maize varieties that tolerate drought and nitrogen-poor soils will reduce farmers' risk, provide incentives to invest in inputs like fertilizer, and allow them to attain food security on a smaller area, freeing up land and labour to grow cash crops, and reducing pressure to open new land.

The interlinked soil fertility problems of acidity, aluminium toxicity, and low phosphorous availability constrain yields on about 4 million ha of cropland worldwide. Also, because maize is grown predominantly as a rainfed crop, increased rainfall variability from climate change (Hulme et al., 2001; Stige et al., 2006) will lead to greater losses due to drought and flooding and therefore frequent production and price variation (Jones and Thornton, 2003). The largest impact on consumer prices comes from relatively favourable production regions, such as areas with an average of 500-800 mm rainfall, where unexpected drought can significantly cut production. Excess rainfall and poor drainage is another severe constraint to maize productivity, particularly during the wet season in areas of Asia that are heavily dependent on monsoon rainfall. In such conditions, maize yields are often approximately one-half to one-third lower than irrigated production in the dry season.

Combinations of stresses are also particularly damaging to crops (Mittler, 2006). The combinations of drought, heat stress and water-logging/excess moisture, coupled with vulnerability to emerging diseases and insect-pests, are likely to increase in some regions, especially in SubSaharan Africa and Asia, with global climate changes. CIMMYT researchers have observed that many inbred/ hybrid/open-pollinated varieties that are tolerant to drought alone perform poorly under conditions of drought combined with high temperature. This indicates that joint screening for both stresses simultaneously will be required to identify tolerant materials, and that tolerance to the combination cannot be predicted from reaction to each stress in isolation. The combination of water-logging early in the season, which impedes root development, and lateseason drought occurs commonly in some areas of South and Southeast Asia.

\section{Biotic stresses}

Losses due to abiotic stresses are often compounded by high incidence of diseases, insect pests and weeds, which on an average can reduce yields by more than $30 \%$. An estimated $54 \%$ of attainable yield is lost annually to diseases (16\%), animals and insects $(20 \%)$ and weeds (18\%) in Africa. Similar losses have been observed for Central and South America (48\%) and Asia (42\%; Oerke, 2006). Efforts to reduce maize losses from diseases and insect pests through host-controlled resistance (biotic stress resistant varieties) offer tremendous opportunities for increasing and stabilizing maize productivity.

Maize diseases of global or regional importance include southern corn leaf blight (Bipolaris maydis), southern rust (Puccinia polysora), northern corn leaf blight (Exserohilum turcicum), common rust (Puccinia sorghi), gray leaf spot (Cercospora species), stalk and ear rots caused by Diplodia and Fusarium, and kernel and ear rots caused by several Fusarium and Aspergillus species, which also contaminate grain with mycotoxins thereby reducing grain quality and safety. Diseases that are particularly important in Asia are the downy mildews, post-flowering stalk rots (PFSR), gray leaf spot, banded leaf and sheath blight (BLSB), and turcicum leaf blight. For Latin America, the tar spot complex and the corn stunt complex diseases are of particular importance. Major biotic stresses limited to Africa include maize streak virus (MSV), and the parasitic weed Striga (Striga asiatica and Striga hermonthica).

The frequency and severity of disease epidemics is dynamic, and while some currently important diseases may become less important as resistant cultivars are developed and deployed, others presently considered unimportant may become more prevalent with changes in climate, cropping practices and introduction of new germplasm (Ward et al., 1997). For example, increased adoption of zero tillage and retention of residue cover has resulted in increased 
incidences and severity of gray leaf spot (Cercospora zeaemaydis). ${ }^{3}$ In Africa, yield reductions of $30-60 \%$ have been attributed to gray leaf spot (GLS), depending on germplasm and environmental conditions (Ward et al., 1997). GLS is now becoming an important disease globally, with high incidences reported in Nepal, China, Colombia, Mexico, Brazil and several countries in Africa. A similar situation has been observed for the tar spot complex (Phyllachora maydis and Monographella maydis) in Latin America, where heavy losses have recently been noted in El Salvador, Guatemala, Mexico, Colombia and Nicaragua.

Insect pests reduce maize production by directly attacking roots (rootworms, wireworms, white grubs, and seedcorn maggots), leaves (aphids, armyworm, stem borers, thrips, spider mites and grasshoppers), stalks (stem borers and termites), ears and tassels (stem borers, earworms, adult rootworms and armyworm), and grain during storage (grain weevils and grain borers). Stem borers are the most damaging group of insect pests in maize cultivation and account for an estimated average annual loss of 18\% (De Groote, 2001). Two species of stem borers (Chilo partellus and Busseola fusca), are common biotic constraints to maize in ESA, while in west and central Africa, the stem borers Sesamia calamistis, Eldana saccharina, and Mussidia nigrivenella are the dominant insect pests of maize, limiting production.

In addition to pre-harvest losses, substantial post-harvest losses (up to $80 \%$ ) have been reported in the tropics from grain weevils (Sitophilus zeamais) and the larger grain borer (Prostephanus truncatus). Minimizing such losses will significantly contribute to nutrition and food security. Storage insect pests, mainly the maize weevil (Sitophilus zeamais), larger grain borer (LGB) (Prostephanus truncatus), angoumois grain moth (Sitotroga cereallela) and the lesser grain weevil (Sitophilus oryzae) cause an estimated $20-30 \%$ loss of maize, thus negatively impacting food security and income generation. Ear and kernel rots of maize, caused by a variety of fungi, are prevalent in warm, humid, tropical and subtropical maize growing environments. About $55.9 \%$ of the area under maize in subtropical, mid-altitude, transition zone and highland zones experience economic losses due to ear rots, and up to $44 \%$ of maize grown in tropical lowlands are lost to ear rots.

\footnotetext{
${ }^{3}$ The Ward et al. (1997) study investigated the interactive effects of four tillage practices leaving varying amounts of surface residues and fungicide treatments for the control of stubble-associated pathogens. In seasons unfavourable for GLS, the onset of disease was 23 days earlier in no-till with higher disease than conventional tillage. However, higher grain yield from conserved soil moisture under notill with residue management was able to offset the detrimental effects of higher disease. The authors conclude that the judicious application of fungicides will be the best approach for retention of residue cover under conservation farming.
}

Economic losses result from reduced grain quality and mycotoxin contamination (especially aflatoxin and fumonisins produced by Aspergillus flavus and Fusarium verticillioides, respectively) making grain unsafe for food and animal feed. Adequate storage facilities are essential to preserve quality, minimize storage losses and maintain food safety for food security. Although substantial research and development efforts have gone into storage, there have been many cases where 'improved' storage technologies have not been taken up by small-scale farmers. This is because many of these technologies turn out to be inappropriate for farmers' needs, or are not available at the right price and the right time (Compton et al., 1993).

\section{Vulnerability to climate change}

Changes in precipitation patterns, caused by climate change, will increase the likelihood of short-term crop failures and long-term production declines. It is anticipated that climate change will increase water scarcity in the coming decades (Lobell et al., 2008). Water scarcity is projected to become a more important determinant of food scarcity than land scarcity and the resulting decline in global per capita food production will threaten future food security (Brown and Funk, 2008; Funk and Brown, 2009). Climate models also show a high probability $(>90 \%)$ that by the end of this century growing season temperatures will exceed the most extreme seasonal temperatures recorded in the past century (Battisti and Naylor, 2009). Hulme et al. (2001) suggest a warming in Africa of between 2 and $6^{\circ} \mathrm{C}$ by 2100 while Ruosteenoja et al. (2003) predict warming of $9^{\circ} \mathrm{C}$ for northern Africa and $7^{\circ} \mathrm{C}$ for southern Africa, between 2070 and 2099.

While an increase in temperature of a few degrees is projected to increase crop yields in temperate areas, in many tropical areas temperature increases are likely to be detrimental to food production because exposure to high temperatures (e.g. $>35^{\circ} \mathrm{C}$ ) can result in a reduction in crop yields by affecting a large array of physiological, biochemical and molecular processes (Lobell et al., 2011). Sensitivity to supra-optimum temperatures and mechanisms of tolerance depend on the severity, duration and timing of heat stress together with the developmental stage of the plant. Higher temperatures eventually reduce yields while encouraging some weed and pest proliferation. The effect of a combination of stresses, such as heat and drought, on crop performance will be greater than the effect of each stress individually.

Extreme weather events that are expected under climate change will also affect the incidence, severity and geographical distribution of maize diseases, especially fungi that incite ear rots and contaminate the grain with 
mycotoxins (Paterson and Lima, 2010). Semi-arid to arid and drought conditions in tropical countries are associated with high levels of mycotoxin contamination. Changes in climate may lead to acute aflatoxicosis and deaths from the consumption of poor crops as occurred in Kenya in 2004 (Strosnider et al., 2006). High incidences of aflatoxin have been reported in Kenya, especially in years of severe droughts (Lewis et al., 2005). Rain, at or near harvest, also could lead to unacceptable concentrations of aflatoxin in many crops in warm regions (Cotty and Jaime-Garcia, 2007). The extent to which crops become vulnerable to attack by insect pests is also affected by prevailing climatic conditions. Higher temperatures and drought conditions are usually more favourable for the proliferation of insect pests and, under dry conditions, the life cycle of insects is shortened, resulting in several generations per growing cycle (Bale et al., 2002).

Climate change is likely to influence food-producing capacity in many areas. While some areas may experience a reduction in crop yields, others are likely to benefit (Raleigh and Urdal, 2007). The impact of climate change on agricultural production will be greatest in the tropics and subtropics, with Africa particularly vulnerable due to the range of projected impacts, multiple stresses and low adaptive capacity (Nelson et al., 2009). Climate change is projected to reduce maize production globally by $3-10 \%$ by 2050 (Rosegrant et al., 2009). Due to higher temperature and reduced rainfall, Jones and Thornton (2003) estimated that crop yields in Africa may fall by $10-20 \%$ by 2050 . However this figure masks variation whereby in some areas crop reductions will be greater (northern Uganda, southern Sudan and the semi-arid areas of Kenya and Tanzania) while in other areas crop yields may increase (southern Ethiopia highlands, central and western highlands of Kenya and the Great Lakes Region; Thornton et al., 2009). Analysis of climate risk identified maize in southern Africa as one of the most important crops in need of adaptation investment (Lobell et al. 2008, 2011). South Asia will also be hard hit by climate change effects, where irrigated yields for all crops will experience significant declines. Maize yields may drop by $17 \%$ in the irrigated areas of South Asia because of climate change-induced heat and water stresses, if current trends persist until 2050.

In a recent study which uses CIMMYT regional data from more than 20,000 historical maize trials in Africa, combined with daily weather data, Lobell et al. (2011) estimated that each degree day spent above $30^{\circ} \mathrm{C}$ reduced the final yield by $1 \%$ under optimal rain-fed conditions and by $1.7 \%$ under drought conditions. The net effect of $1{ }^{\circ} \mathrm{C}$ warming on maize yields was also different under drought and optimal growing conditions. For optimal management, at present, maize growing at an average of less than $23^{\circ} \mathrm{C}$ tends to gain from warming, whereas yields of maize grown in areas above this baseline temperature tend to decline with warming. Sites above $25^{\circ} \mathrm{C}$ in average temperature decline quite rapidly because of frequent exposure to temperatures above $30^{\circ} \mathrm{C}$, with more than $10 \%$ yield loss per $1{ }^{\circ} \mathrm{C}$ of warming. Under drought conditions, even the coolest trials are harmed by $1{ }^{\circ} \mathrm{C}$ warming, with losses exceeding $40 \%$ at the hottest sites. Roughly $65 \%$ of present maize-growing areas in Africa would experience yield losses for $1^{\circ} \mathrm{C}$ of warming under optimal rain-fed management, with $100 \%$ of areas harmed by warming under drought conditions (Lobell et al., 2011).

The impact of climate change also includes potential displacement of environmental refugees. There are gloomy predictions of how environmental crises will impact global security and the geopolitical status quo. The environmental problems associated with climate change could play a role in causing migration which can lead to conflict in receiving areas: the arrival of "environmental migrants" can burden the economic and resource base of the receiving area, promoting native-migrant contest over resources such as cropland and freshwater (Raleigh and Urdal, 2007). Climate change is also likely to undermine the capacity of states to provide the opportunities and services that help people to sustain their livelihoods and which help to maintain and build peace. In certain circumstances, these direct and indirect impacts of climate change on human security and the state may in turn increase the risk of violent conflict.

Farmers in all regions have developed different coping mechanisms for adapting to the impacts of climate variability. However, climate change represents an enormous challenge which will test their ability to adapt and improve their livelihoods in order to escape poverty and under nourishment. Adaptation to climate change will be difficult and complex in regions projected to be hit hardest and where institutional, financial and technological capacity is limited (e.g. Africa). Given the projected impacts of climate change on food security, more attention needs to be directed at the generation of stress tolerant and widely adapted crop varieties along with improved agronomic practices. Maize research has a critical role to play in stimulating adaptation to and mitigation of climate change in vulnerable areas. Maize varieties with increased tolerance to abiotic stresses (drought, heat and water-logging) and resistance to diseases and insect-pests are important for managing current climatic variability and for adaptation to future climate change. Furthermore, sustainable agronomic and resource management practices, such as conservation agriculture and precision agriculture, can effectively contribute to climate change mitigation (see section 6 below).

In addition to technological solutions, there is also a need for better policies, institutional arrangements and investments in infrastructure that create enabling conditions to adopt and adapt new technologies and innovations. 
These include investments in irrigation, roads, storage facilities and improved access to markets. Enhanced capacity for adaptation will also require policy innovations for stabilizing prices, diversifying incomes, increasing farmer access to improved seeds, finance, insurance products and productive safety nets to protect the poor and support resilience of vulnerable livelihoods.

\section{Future technology options}

Improved germplasm and novel technologies

The development and dissemination of improved germplasm and risk-reducing management options have the potential to offset some of the yield losses linked to climate change and other abiotic and biotic stresses. Much attention needs to be directed at the generation of stress-tolerant and widelyadapted maize varieties. Research is required into the identification of traits associated with combined heat and drought tolerance, and the development of improved germplasm for high temperature and water-limited environments.

The development of improved germplasm for meeting persistent and emerging challenges related to changing climates can be made through a combination of conventional, molecular and transgenic breeding approaches. Improvement in the levels of defensive traits, including tolerance to drought, low $\mathrm{N}$ fertility, water-logging, heat, and acid soils, and resistance to diseases, insects and the parasitic weed Striga, can significantly reduce the risk associated with planting under rain-fed conditions and may promote the use of other inputs and improved management practices. Breeding for drought tolerance often offers high returns to investment not only in Sub-Saharan Africa (La Rovere et al., 2010), but also for rainfed maize production in Asia (Gerpacio and Pingali, 2007). Maize offers great potential as a rainfed crop to follow rice at the end of the monsoon, or as the main crop in areas where water availability is marginal or inadequate for rice. To realize this potential, maize varieties are needed that tolerate drought late in the growing cycle, during flowering and the grain filling stages.

Changes in rainfall distribution will also result in increased temporary excessive soil moisture or waterlogging in maize production areas. Water-logging regularly affects over $18 \%$ of the total maize production area in South and Southeast Asia (Zaidi et al., 2010). The development of improved germplasm, with combined drought and excessmoisture tolerance, will be necessary to cope with climate extremes in many areas of Africa, Asia and Latin America. Recent research shows good potential for increasing waterlogging tolerance in maize (Zaidi et al., 2010). Development of improved germplasm with tolerance to combina- tions of abiotic stresses warrant development of new screening/phenotyping approaches and breeding strategies.

Favourable gene combinations contributing to higher yield or stress tolerance or nutritional quality do exist in the gene pools of primary maize and wild relatives. These can be used for breeding new high yielding, stress tolerant and nutritionally enriched cultivars using conventional approaches. However, these desirable genes/alleles and their combinations are scattered over various different landraces, populations or genotypes, where they often occur at low frequencies. The future of maize breeding will depend on more efficient techniques for the discovery of these novel and informative alleles (alternative versions of a gene), haplotypes (combinations of alleles or DNA sequences at different closely linked sites/genes on the same chromosome and tend to be inherited together) and gene combinations than those currently available. Significant strides have been made in the past two decades in understanding the phenotypic and molecular diversity in the maize germplasm, identification of genes/ QTLs (Quantitative Trait Loci) influencing diverse traits, especially for tolerance to biotic and abiotic stresses and nutritional quality traits (Prasanna et al., 2010). Emerging molecular breeding technologies thus offer new highthroughput approaches which could ensure the development of adapted germplasm for future climates.

Among the genetically modified (GM) crops, maize has an important place along with soybean, cotton and canola. Of the 29 Biotech/GM crop-growing countries, 16 have GM maize. Over one-quarter of the global maize area is transgenic (James, 2011). Several transgenic maize products have been developed and released in the USA, mostly by multinational companies. A series of transgenic maize products are in the pipeline for release in developing countries (e.g. China, Brazil, South Africa etc.), including Bt maize, herbicide tolerant maize, maize with resistance to Maize Streak Virus (MSV), and those with stacked traits. Where limited genetic variation in maize exists for key traits such as drought tolerance, nutrient use efficiency and herbicide resistance, transgenic breeding would be an important option to pursue.

The ability to develop quickly germplasm combining tolerance to several complex polygenically inherited abiotic and biotic stresses will be critical for the resilience of cropping systems to climate change. Conventional breeding methods that rely on extensive phenotypic screening are effective but slow in producing widely adapted germplasm and are not optimal for rapidly improving tolerance to multiple stresses. Enhanced understanding of the physiological basis of drought tolerance, coupled with advances in instrumentation, are important in integrating high throughput and cost-effective field-based phenotyping methods in breeding for abiotic stress tolerance (Araus et al., 2008). Although the scientific community currently relies heavily 
on phenotypic evaluations and/or wet chemistry for important traits, imaging techniques that allow immediate and non-invasive detection of plant characteristics, before visual appearance of phenotypes are gaining prominence, as they aid in high throughput profiling of phenotypic characteristics. With the fall in genotyping costs, new genomic selection technologies have become available that allow the breeding cycle to be greatly reduced, facilitating the inclusion of information on genetic effects for multiple stresses in selection decisions (Heffner et al., 2009). The challenge is also to identify, validate and integrate use of molecular markers associated with major genes/QTLs for important oligogenic (simply inherited) defensive and nutritional quality traits in breeding programs (Prasanna et al., 2010).

Another important avenue for improving breeding efficiency is the use of doubled haploid (DH) technology in facilitating development of genetically pure parental lines for developing hybrids in a timely and cost-effective manner (Röber et al., 2005). Use of DH technology to develop inbred lines rapidly is widespread among commercial maize breeding programs particularly in Europe and the USA. Further research is required to develop protocols that can effectively combine DH technology with molecular markers and transgenes (especially stacked transgenes for different traits) for enhancing genetic gains and breeding progress (Prasanna et al., 2010).

Improving the uptake and use efficiency of nutrients, particularly nitrogen and phosphorous, could significantly contribute to securing world food and feed production and raise agricultural incomes. Globally, nutrient use efficiency is among the most important factors limiting crop productivity and yield stability in both high potential-low risk environments as well as low potential-high risk environments. Obviously, genetics and breeding alone cannot solve this complex challenge. Improved agronomic practices, especially conservation agriculture, have significant roles to play. In addition, agronomists and geneticists/breeders have to work in tandem to identify cultivars that respond best to such practices, and for generating better understanding of the complex interactions between genotype $\mathrm{x}$ environment $\mathrm{x}$ management practices.

Improvement of nutritional quality in food crops (biofortification) is a promising strategy to combat under-nutrition, particularly among the rural poor in developing countries. The development of Quality Protein Maize (QPM) by CIMMYT is a major milestone in maize breeding and biofortification. Many maize breeding programs operating in Africa, Latin America, and parts of Asia are currently developing QPM varieties to improve nutrition and health of local populations (Krivanek et al., 2007). To enhance the adoption and impact of QPM varieties, it is important to enhance their productivity and tolerance to biotic and abiotic stresses. Another important breeding objective is improving the pro-vitamin A content of maize grain. Research under the HarvestPlus project has provided significant leads for developing micronutrientenriched maize, especially for kernel-zinc and pro-vitamin A (Harjes et al., 2008; Yan et al., 2010). Methionine is an essential amino acid that is often limiting in maize-based diets and is the primary growth-limiting amino acid for chicken in the poultry industry (Hellin and Erenstein, 2009). Methionineenriched maize, developed either through conventional breeding (Scott et al., 2004) or genetic engineering (Lai and Messing, 2002) has high potential in the poultry industry as a substitute for costly synthetic methionine.

\section{Conservation agriculture}

Agronomy, including soil fertility and water management and weed control, are key determinants of crop productivity in the tropics. Climate change will be especially detrimental to crop production in cropping systems where soils have been degraded to a point where they no longer provide sufficient buffer against drought and heat stress. These effects will be most severe if irrigation water is not available to compensate for decreased rainfall or to mitigate the effects of higher temperatures. These problems cannot be addressed by improving genetic adaptation to heat or drought stress alone and will require agronomic interventions (Hobbs and Govaerts, 2010).

Scientists are therefore developing improved cropping systems and management practices, often referred to as conservation agriculture. This involves significant reductions in tillage, enhanced surface retention of adequate crop residues and diversified, economically viable crop rotations. As a result, there has been increased growth in productivity, more efficient use of water and soil nutrients and savings in the costs of fuel and labour (Hobbs and Govaerts, 2010). Conservation agriculture also enhances soil carbon sequestration and reduces $\mathrm{CO}_{2}$ emissions by reducing tillage (and hence use of fossil fuels) and by reducing the burning of crop residues, thus contributing to both adaptation to and mitigation of climate change.

There is little doubt that research on crop and resource management to overcome seasonal labour constraints and to maximize returns to cash inputs, while conserving the soil base and enhancing soil fertility over the longer run, will go a long way toward increasing productivity and sustainability of maize-based systems. Research on these constraints has increased sharply in the past decade but success, measured in terms of adoption, has not been impressive. While early experience has been positive, adoption is still limited and considerable research is needed to adapt conservation agriculture practices to locallyspecific biophysical and socioeconomic conditions especially for resource poor smallholder farmers in Africa 
(Giller et al., 2009). The use of crop residue and maize stover for feeding livestock as well as for cooking and heating creates trade-offs that reduce incentives for farmers to use these resources for soil fertility management. Availability of equipment for direct seeding or minimal tillage operations is another constraint that needs to be addressed in developing locally adapted options for conservation agriculture.

Precision agriculture tools that allow a more efficient use of nitrogen if fully developed and made profitable can also offer win-win solutions in terms of low costs of production and significant reduction in the emission of nitrous oxide, a powerful green house gas. Currently, more than $70 \%$ of all nitrogen fertilizer is applied in the developing world. CIMMYT is working on new approaches that enhance the efficiency of fertilizer applications and reduce the overall demand for $\mathrm{N}$ fertilizers by small-scale farmers.

\section{Socioeconomics and policy research}

Past experiences from successes in Asia and other regions have clearly demonstrated that technology adoption and impact at scale is a function of the 'hard' technology (e.g. good germplasm and agronomy) as well as the institutional innovations and policies that ensure farmer access to information, new seeds, complementary inputs and reliable markets for selling surplus produce at prices that will make investments in new technologies attractive to smallholder farmers. These institutional and policy innovations may as well be considered as 'soft technologies' without which the 'hard technologies' alone will not make much impact. An integrated approach that links the biophysical and the socioeconomic work is essential for success in improving productivity of maize and in enhancing adaptation to changing climate. Socioeconomic and policy research often provide information that contributes to the better understanding of the context in which new technologies will need to work and can facilitate the targeting, design and development of appropriate technologies that will have high adoption potential by resource poor farmers. For example, the access to and scarcity of resources such as land, labour, water, traction power, capital and output markets can be important factors that will determine the kind of technology that is suitable for a given region and will inform the process of technology development and diffusion.

Many farmers in the developing regions face several barriers to adopting new and potentially profitable or attractive varieties and agronomic practices. These widen the yield and productivity gap. Access to information, input and output markets and services play a critical role in closing this gap. Given the time-lag between technology development, deployment and on-farm adoption of new varieties, there is a continuing need for research to identify institutional innovations and policy options that facilitate farmers' access to existing and new varieties as well as yield-enhancing and risk-reducing management practices. Socioeconomic and spatial agroclimatic research is also needed to understand and map the climate hotspots, vulnerability of livelihoods, current coping strategies and adaptation options and the institutional and policy mechanisms that promote adoption of new technologies and enhance local adaptive capacity to climate change. Breeding and agronomic research therefore need to be intimately linked to social science research which will help in the understanding of the context in which development is to take place. This should result in the development of practical products such as institutional innovations, access to seeds, credit, insurance and markets and should help to overcome other barriers that currently limit farmer investment in new technologies.

\section{Constraints to the adoption of available technologies}

\section{Strengthening seed systems}

More than half of the developing world's maize area is still planted to unimproved varieties. For example, it is estimated that in the late 1990 s approximately $48 \%$ of the total maize area in ESA was planted using farm-saved seed (Hassan et al., 2001). This figure rises to $64 \%$ when South Africa is excluded. For Latin America, some $55 \%$ of the total maize area at the end of the 1990s was planted using farm-saved seed, and for Asia (excluding China) the figure was approximately 35\% (Morris et al., 2003). The use of recycled farm-saved seed or unimproved varieties is one of the most important factors that limit the productivity of maize in several countries in the developing world, unlike the situation in the developed countries, where $98-100 \%$ of the maize area is under single-cross hybrids. Poor seed production and distribution continue to slow the adoption of improved maize germplasm by resource-poor farmers in the developing world.

The most recent estimates place the adoption of improved open-pollinated varieties (OPVs) and hybrids at $44 \%$ of the maize area in ESA in 2006-07 (excluding South Africa) and $60 \%$ in West and Central Africa in 2005. Despite evidence of dynamic change in the seed sector, data indicate that roughly half of Sub-Saharan Africa's maize area continues to be planted to farmers' varieties, though through cross-pollination and farmer selection, breeders often suggest that many of these have been influenced by proximity to modern maize. The relatively low adoption levels persist despite the fact that the push towards liberalization and restructuring of the seed sector in ESA 
during the past two decades has witnessed a proliferation of private seed companies in the maize seed industry (Langyintuo et al., 2010).

A recent study under the DTMA (Drought Tolerant Maize for Africa) project revealed a number of institutional bottlenecks affecting the maize seed value chain, particularly in the area of policy, credit availability, seed production, germplasm and marketing. In 1997, there were 19 registered maize seed companies in Angola, Ethiopia, Kenya, Malawi, Mozambique, Tanzania, Uganda, Zambia and Zimbabwe that produced and marketed 49,000 tons of seed. In 2007, there were 80 companies in the same nine countries that produce and market just over 100,000 tons of seed. Given that the number of seed companies increased four-fold between 1997 and 2007 but the quantity of seed marketed barely doubled suggests that there are inefficiencies in the seed production and deployment environment (Langyintuo et al., 2010).

Despite efforts to liberate the input markets, the seed sector in many countries remains largely under the direct control of the state. For example, approximately $70 \%$ of maize seed in Ethiopia, mostly hybrid, was still produced by ESE (Ethiopian Seed Enterprise). Not surprisingly, purchased seed in 2007-8 accounted for just $20 \%$ of the area under maize cultivation in this country (Spielman et al., 2010).

Langyintuo et al. (2010) concluded that the major bottlenecks in the seed industry were lack of awareness of the availability and value of existing varieties, the high relative price of seed because of poor and uncompetitive grain prices, and lack of credit. The supply of pre-basic and basic seed that is used in the production of certified seed is a major supply side constraint in the provision of quality seed to farmers. The adoption of progressive seed laws and regulations with effective harmonization of seed trade will improve regional trade in seed and farmers' access to improved maize varieties adapted to local conditions. To promote growth and development of the maize seed industry, it is imperative for a coordinated intervention effort by both public and private sector players to address the various bottlenecks. The collection, processing, dissemination and management of information on varietal release and adaptation remain vital in ensuring success of the coordinated effort.

Extension services and innovation systems

Most new technologies that will become available to farmers will be 'information intensive', i.e., they will require increased levels of knowledge for appropriate management. Extension provision, therefore, plays a role in bringing new ideas to farmers and educating them about promising technology options as well as linking them to new networks which may play important roles in facilitating their access to new technologies and services. However, the need for more responsive extension provision has coincided with deep cuts in publiclyfunded extension services in many developing countries. Extension needs to play an important role in demonstrating new technologies to farmers and stimulating local innovation systems for participatory adaptation of innovation, especially knowledge intensive integrated crop and natural resource management systems.

The breakdown of classical publicly-funded agricultural extension services means that these services are now unable to address the needs of many farmers, especially those living in marginal environments. Private extension provision was expected to replace that previously provided by government. In the majority of cases, however, the private sector has proved incapable of replacing previous state services due to high transaction costs, dispersed clientele, and low (or non-existent) profits. If services are only offered where demand already exists, there is a risk that private sector providers will serve only the better-off farmers and ignore those living in less favoured areas (Muyanga and Jayne, 2008). Weak extension systems also make it hard for farmers to access information about new varieties. When information is sketchy and imperfect, the seed replacement system fails and farmers plant very old OPVs or hybrids using farm saved impure seed.

Key components of extension provision include: disseminating locally adapted, high yielding and stress tolerant crop varieties; innovation systems to develop and adapt improved management systems; and gathering information to facilitate national research work. Other services are also critical. The breeding and agronomic research work needs to be supported by other factors including (i) complementary investments in climate-responsive information and input delivery systems; (ii) a strengthening of institutions for provision of market information and coordinating seed marketing with supply of fertilizer and credit delivery, and (iii) strategies for scaling up/out promising innovations to wider target areas to reach the poor and women farmers in less favoured regions.

New approaches to extension provision are needed along with a new consensus on the role of the public and private sectors and how extension provision for resource-poor farmers can be provided on a more sustainable basis. Both the private and public sectors clearly have key roles to play in contributing to the provision of extension services. The separation of delivery and financing of extension results in four main extension modalities that can be used to enhance farmers' access to improved maize seed:

- Private delivery and private financing (totally private extension) 
- Private delivery and public financing (contracting out)

- Public delivery and public financing (typical government extension service)

- Public delivery and private financing (contracting in)

Several pilot projects and especially the SasakawaGlobal 2000 (SG 2000) demonstrations on farmers' fields have shown that there is considerable potential to raise maize yields in Sub-Saharan Africa, and have served as a reminder that rapid adoption of new technologies is possible in medium-to high potential areas when relevant technology is combined with input delivery systems and market opportunities. Yields in thousands of large plot demonstrations typically averaged from 4-5 t/ha against average national yields of $1-1.5 \mathrm{t} / \mathrm{ha}$. Nonetheless, when programs were withdrawn, the realities of overcoming input supply discontinuities, extending supply chains into remote rural areas, and forging solvent local agro-enterprises persisted.

Input vouchers redeemable at private input dealers and targeted to farmers who use little fertilizer have been the main vehicle for implementing smart subsidies (e.g. Malawi). In response to the 2005/06 crisis, the government initiated the Agricultural Input Subsidy Programme (AISP). AISP provides about $50 \%$ of farm households with vouchers for $100 \mathrm{~kg}$ of fertilizer and small quantities of maize (and lately legume) seed, with mainly privately imported fertilizers delivered principally, and in some years exclusively, by two parastatal input suppliers. The main challenge with this kind of approach is to minimize leakages and to enhance the targeting of the poor, using market based input delivery systems (Dorward et al., 2009).

Agricultural extension should not only play a role in disseminating information and seed technologies but also stimulate local innovation. In the linear vision, innovation results from the creation of knowledge through basic scientific research, followed by strategic, applied, and adaptive research, and ultimately to technology development, dissemination and adoption. Agricultural development, however, is an immensely complex process characterized by a high degree of nonlinearity. Hence, in place of a linear approach, what is needed is an "innovation systems" approach in which innovation is the result of a process of networking, interactive learning and negotiation among a heterogeneous set of actors (Davis et al., 2008). An innovation system consists of a web of dynamic interactions among researchers, extension agents, equipment manufacturers, input suppliers, farmers, traders, and processors. In a vibrant innovation system, agricultural development results from efforts to combine technological improvements in production (e.g. improved maize seed), processing, and distribution with organizational improvements in how information and knowledge are exchanged between various actors along with policy changes that create favourable incentives and institutions to promote local innovation and adaptation of technologies.

Imperfect markets and asset constraints

Other related constraints include those of cash and credit provision and under-developed marketing systems for commercializing maize under smallholder systems. Poor commercialization makes it hard for farmers to sustain their investments in new technologies (hybrid seed, fertilizer, etc). When markets collapse (e.g. maize markets in Ethiopia in 2001), they lack incentives and go back to their traditional systems based on semi-subsistence farming.

As a result, adoption has also been uneven in high and low potential areas and resource poor and marginal farmers often lag behind in terms of technology adoption because of asset constraints and market imperfections. When the credit, labour, traction power and land markets are imperfect, farmers who lack the necessary capital or family resources (labour, land, oxen) will fail to invest in otherwise profitable technologies. For example, experience from many African countries has shown that seasonal labour availability is an important constraint to the acceptance of improved management practices that are relatively labour intensive, such as plant spacing and weeding. If these are recommended as a package with fertilizer and seed, the profitability of other components is also affected. Even where land is in short supply, seasonal labour shortages often decisively influence farmers' choice of technology for several reasons: hand-hoe agriculture demands a great deal of labour, off-farm work is important in many areas, and a pool of landless rural labourers is not available when demand for labour is greatest. Improving the functioning of factor markets and credit to smallholder farmers enhances opportunities for developing successful value chains that promote adoption of new varieties and management practices. Overcoming such market and institutional imperfections will play a critical role in reaching the poor and women farmers and promoting inclusive and equitable growth in maize growing areas.

\section{Conclusions}

Maize is one of the three most important cereals for food security at the global level and is of particular importance in the diets of the poor in Africa and Latin America. Its contribution in terms of calories and protein derived from cereals ranges from $61 \%$ in Mesoamerica, to $45 \%$ in ESA, $29 \%$ in the Andean region, and $21 \%$ in WCA. Given its diversified uses and market demand, maize production also contributes indirectly to food security and poverty reduction 
in the developing regions through income growth even when the produce is sold for other non-food uses (e.g. feed). In many developed countries and the emerging economies of Asia and Latin America, maize is increasingly being used as an essential ingredient in the formulation of livestock feed. With growing demand for livestock products and changing dietary patterns in populous developing regions, the demand for maize is projected to double by 2050 . Whereas yields remain very low in many developing regions, the challenge of closing the yield gap and accelerating production by developing new high yielding varieties is further complicated by the threat of climate change.

Maize is a popular crop for many smallholder farmers in different regions, mainly because of its wide adaptability, high yields and valuable by-products (e.g. stover used as fodder for feeding livestock). The dramatic growth in production at the global level during the past 50 years was mainly possible through yield growth and area expansion in the developing countries. Except in subSaharan Africa where yield has only grown by about $1.2 \%$ annually since the 1960 s, many other regions saw a productivity growth of more than $2 \%$ per year. This paper shows that smallholder maize production in developing countries is stymied by technological, biophysical and socioeconomic constraints. The biotic and abiotic stresses that limit maize production and productivity include a combination of factors such as drought, heat, poor soil fertility and water-logging/excess moisture, coupled with vulnerability to emerging diseases and insect pests which are likely to increase in some regions, especially in Africa and Asia, with global climate changes.

Future productivity growth to meet the growing demands for maize will require holistic approaches that not only help sustain current yields but substantially increase crop productivity under variable and changing climate. Experiences from the Green Revolution in Asia also indicate that technology alone will not solve the problem. The review of past successes and future opportunities undertaken in this paper show the importance of continued investment in agricultural research and of addressing policy and institutional constraints such as those hindering access to information, technologies, inputs and markets which continue to undermine farmers' incentives to invest in the adoption and adaptation of new maize technologies.

Over the long term, large public and private sector investment and sustained political commitment are needed to ensure strong support of plant breeding and innovations in seed and input supply systems. These will enhance farmer access and use of improved seed and complementary inputs as well as improved crop management practices which will protect soils and cope with unpredictable climatic conditions. More innovative extension and advisory systems are also needed to facilitate farmer learning, rather than deliver packages.The maize productivity gains achieved through smallholder adoption of improved seed and fertilizer during the 1980s in Africa were driven by appropriateness of the technologies and enabling marketing and support policies that encouraged their use. The state can play an important role in creating the enabling institutional environment as well as directly investing in research, infrastructure and services, especially when the private sector lacks the incentives to work in certain regions.

Adapting to climate change is going to be more difficult for many smallholder maize farmers in Africa, Asia and Latin America. CIMMYT along with IITA and national partners is developing various maize technologies and policy and institutional innovations to help raise the productivity of maize and enhance adaptation options for farmers. Among other things, the range of options being developed include widely adapted hybrids and OPVs of drought tolerant maize, water efficient maize, maize for low nitrogen soils, insect resistant maize, and quality protein maize to meet the nutritional needs of consumers who rely on maize as their main source of calories. The partnership is also working on strategies for sustainable intensification of maize systems through best-bet agronomic practices and integration of legumes and other crops for system diversification. Farming based on the principles of conservation agriculture that involves reductions in tillage, improved retention of crop residues, and diversified and economically viable crop rotations, also contributes to increase yields and resilience of farming systems. The development of such more sustainable systems will enhance income and nutrition for the poor while also contributing to both adaptation to and mitigation of climate change.

Responding effectively to the threats of climate change to maize production and food security and managing price surges will require sustained and increased investment to address multiple stresses (e.g. drought plus heat, disease and insect damage) as well as scaling up/out some of the proven technologies and institutional innovations. There is significant potential to increase production in many regions where farmers have not adopted available and profitable technologies mainly because of limitations in accessing information, seeds and input markets as well as underdeveloped value chains for marketing surplus produce. Investments in developing future technologies need to be complemented by strategies and firm commitments from developing country governments and partners to upscale these innovations. They should then be made available to farmers and smallholder producers through enhanced support for extension, increased inputs and value chain development in order to reduce transaction costs and remedy market impediments that currently limit farmers' access to improved technologies and services. 
Open Access This article is distributed under the terms of the Creative Commons Attribution Noncommercial License which permits any noncommercial use, distribution, and reproduction in any medium, provided the original author(s) and source are credited.

\section{References}

Araus, J. L., Slafer, G. A., Royo, C., \& Serret, M. D. (2008). Breeding for yield potential and stress adaptation in cereals. Critical Reviews in Plant Science, 27, 377-412.

Bale, J., Masters, G., Hodkinson, I., Awmack, C., Bezemer, T., Brown, V., et al. (2002). Herbivory in global climate change research: direct effects of rising temperature on insect herbivores. Global Change Biology, 8, 1-16.

Battisti, D. S., \& Naylor, R. L. (2009). Historical warnings of future food insecurity with unprecedented seasonal heat. Science, 323, 240-244.

Brown, M. E., \& Funk, C. C. (2008). Food security under climate change. Science, 319(5863), 580-581.

Byerlee, D., \& Heisey, P. W. (1997). Evolution of the African Maize economy. In D. Byerlee \& C. K. Eicher (Eds.), Africaś emerging maize revolution. Boulder: Lynne Rienner Publishers.

Compton, J. A. F., Tyler, P. S., Hindmarsh, P. S., Golob, P., Boxall, R. A., \& Haines, C. P. (1993). Reducing losses in small farm grain storage in the tropics. Tropical Science, 33, 283-318.

Cotty, P. J., \& Jaime-Garcia, R. (2007). Influences of climate change on aflatoxin producing fungi and aflatoxin contamination. International Journal of Food Microbiology, 119, 109-115.

Davis, K. E., Ekboir, J., \& Spielman, D. J. (2008). Strengthening agricultural education and training in sub-Saharan Africa from an Innovation Systems Perspective: a case study of Mozambique. The Journal of Agricultural Education and Extension, 14(1), 35-51.

De Groote, H. (2001). Maize yield losses from stem borers in Kenya. Insect Science and Applications, 22, 89-96.

Delgado, C. J. (2003). Rising consumption of meat and milk in developing countries has created a new food revolution. The Journal of Nutrition, 133, 3907S-3910S.

Delmer, D. P. (2005). Agriculture in the developing world: connecting innovations in plant research to downstream applications. Proceedings of the National Academy of Sciences, 102(44), 15739-15746.

Dorward, A. R., Kydd, J. G., Poulton, C. D., \& Bezemer, D. (2009). Coordination risk and cost impacts on economic development in poor rural areas. Journal of Development Studies 45(7).

Evenson, R. E., \& Gollin, D. (2003). Assessing the impact of the green revolution, 1960 to 2000. Science, 300, 758-762.

FAOSTAT. (2010). Statistical databases and data-sets of the Food and Agriculture Organization of the United Nations. http://faostat.fao. org/default.aspx. Accessed April 2010.

Funk, C. C., \& Brown, M. E. (2009). Declining global per capita agricultural production and warming oceans threaten food security. Food Security, 1, 271-289.

Gerpacio, R. V., \& Pingali, P. L. (2007). Tropical and subtropical maize in Asia: production systems, constraints, and research priorities. Mexico: CIMMYT.

Giller, K. E., Witter, E., Corbeels, M., \& Tittonell, P. (2009). Conservation agriculture and smallholder farming in Africa: the heretics' view. Field Crops Research, 114, 23-34.

Gunaratna, N. S., De Groote, H., \& McCabe, G. P. (2008). Evaluating the impact of biofortification: A meta-analysis of communitylevel studies on Quality Protein Maize (QPM), Paper presented to the European Association of Agricultural Economists, 2008 International Congress, August 26-29, 2008, Ghent, Belgium.

Harjes, C. E., Rocheford, T. R., Bai, L., et al. (2008). Natural genetic variation in Lycopene epsilon cyclase tapped for maize biofortification. Science, 319, 330-333.
Hassan, R. M., Mekuria, M., \& Mwangi, W. M. (2001). Maize breeding research in eastern and southern Africa: Current status and impacts of past investments by the public and private sectors, 1966-1997. Mexico: CIMMYT.

Headey, D., \& Fan, S. (2010). Reflections on the global food crisis. How did it happen? How has it hurt? And how can we prevent the next one? Research Monograph 165. Washington, DC: International Food Policy Research Institute (IFPRI).

Hellin, J., \& Erenstein, O. (2009). Maize-poultry value chains in India: implications for research and development. Journal of New Seeds, 10(4), 245-263.

Heffner, E. L., Sorrells, M. E., \& Jannink, J.-L. (2009). Genomic selection for crop improvement. Crop Science, 49, 1-12.

Heisey, P. W., \& Edmeades, G. O. (1999). Maize production in drought-stressed environments: Technical options and research resource allocation. CIMMYT World Maize Facts and Trend 1997/1998: Mexico, D.F.

Hobbs, P. R., \& Govaerts, B. (2010). How conservation agriculture can contribute to buffering climate change. In M. P. Reynolds (Ed.), Climate change and crop production (p. 151-176). CABI Series in Climate Change.

Hulme, M., Doherty, R., Ngara, T., New, M. G., \& Lister, D. (2001). African climate change 1900-2100. Climate Research, $17,145-168$.

James, C. (2011). Global status of commercialized biotech/GM crops: 2010. Brief 42. ISAAA (http://www.isaaa.org).

Jones, P. G., \& Thornton, P. K. (2003). The potential impacts of climate change on maize production in Africa and Latin America in 2055. Global Environment Change, 13, 51-59.

Krivanek, A. F., De Groote, H., Gunaratna, N. S., Diallo, A. O., \& Friesen, D. (2007). Breeding and disseminating Quality Protein Maize (QPM) for Africa. African Journal of Biotechnology, 6, 312-324.

La Rovere, R., Kostandini, G., Tahirou, A., Dixon, J., Mwangi, W., Guo, Z., et al. (2010). Potential impact of investments in drought tolerant maize in Africa. Addis Ababa, Ethiopia: CIMMYT.

Lai, J., \& Messing, J. (2002). Increasing maize seed methionine by mRNA stability. Plant Journal, 30, 395-402.

Langyintuo, A. S., Mwangi, W., Diallo, A. O., MacRobert, J., Dixon, J., \& Bänziger, M. (2010). Challenges of the maize seed industry in eastern and southern Africa: a compelling case for private-public intervention to promote growth. Food Policy, 35, 323-331.

Lewis, L., Onsongo, M., Njapau, H., Schurz-Rogers, H., Luber, G., Kieszak, S., et al. (2005). Aflatoxin contamination of commercial maize products during an outbreak of acute aflatoxicosis in eastern and central Kenya. Environmental Health Perspectives, $113,1763-1767$.

Lobell, D., Burke, M., Tebaldi, C., Mastrandera, M., Falcon, W., \& Naylor, R. (2008). Prioritizing climate change adaptation needs for food security in 2030. Science, 319(5863), 607-610.

Lobell, D. B., Bänziger, M., Magorokosho, C., \& Vivek, B. (2011). Nonlinear heat effects on African Maize as evidenced by historical yield trials. Nature Climate Change, 1, 42-45.

McCann, J. C. (2005). Maize and Grace: Africas' encounter with a new world crop, 1500-2000. Cambridge: Harvard University Press.

Mittler, R. (2006). Abiotic stress, the field environment and stress combination. Trends in Plant Science, 11, 15-19.

Morris M., Mekuria M., \& Gerpacio R. (2003). In: Evenson R. E., \& Gollin, D. (Eds), Crop variety improvement and its effect on productivity: The impact of International Agricultural Research (pp. 135-158). Wallingford: CABI.

Morris, M., Kelly, V. A., Kopicki, R. J., \& Byerlee, D. (2007). Fertilizer use in African agriculture: Lessons learned and good practice guidelines. Washington, D.C: World Bank.

Muyanga, M., \& Jayne, T. S. (2008). Private agricultural extension system in Kenya: practice and policy lessons. Journal of Agricultural Education and Extension, 14(2), 111-124. 
Nelson, G. C., Rosegrant, M. W., Koo, J., Robertson, R., Sulser, T., Zhu, T., et al. (2009). Climate change impacts on agriculture and costs of adaptation. Research Report, International Food Policy Research Institute, Washington DC.

Oerke, E. C. (2006). Crop losses to pests. Journal of Agricultural Science, 144, 31-43.

Paterson, R. R. M., \& Lima, N. (2010). How will climate change affect mycotoxins in food? Food Research International, 43(7), 1902-1914.

Prasanna, B. M., Pixley, K. V., Warburton, M., \& Xie, C. (2010). Molecular marker-assisted breeding for maize improvement in Asia. Molecular Breeding, 26, 339-356.

Raleigh, C., \& Urdal, H. (2007). Climate change, environmental degradation and armed conflict. Political Geography, 26(2007), 674-694.

Röber, F., Gordillo, G. A., \& Geiger, H. H. (2005). In vivo haploid induction in maize - performance of new inducers and significance of doubled haploid lines in hybrid breeding. Maydica, 50, 275-283.

Rosegrant, M. R., Ringler, C., Sulser, T. B., Ewing, M., Palazzo, A., Zhu, T., et al. (2009). Agriculture and food security under global change: Prospects for 2025/2050. Washington, D.C: International Food Policy Research Institute.

Ruosteenoja, K., Carter, T.R., Jylhä, K., \& Tuomenvirt, H. (2003). Future climate in world regions: An intercomparison of modelbased projections for the new IPCC emissions scenarios. Finnish Environment Institute, No. 644, Helsinki.

Scott, M. P., Bhatnagar, S., \& Betran, J. (2004). Tryptophan and methionine levels in quality protein maize germplasm. Maydica, 49, 303-311.

Smale, M., Byerlee, D., \& Jayne, T. (2011). Maize revolutions in SubSaharan Africa. Forthcoming, World Bank, Washington, DC, and Tegemeo Institute, Kenya

Spielman, D. J., Byerlee, D., Alemu, D., \& Dawit, K. (2010). Policies to promote cereal intensification in Ethiopia: the search for appropriate public and private roles. Food Policy, 35, 185-194.

Stige, L. C., Stave, J., Chan, K. S., Ciannelli, L., Pettorelli, N., Glantz, M., et al. (2006). The effect of climate variation on agro-pastoral production in Africa. Proceedings of the National Academy of Sciences, USA, 103, 3049-3053.

Strosnider, H., Azziz-Baumgartner, E., Banziger, M., Bhat, R. V., Breiman, R., Brune, M. N., et al. (2006). Work group report: public health strategies for reducing aflatoxin exposure in developing countries. Environmental Health Perspectives, 114, 1898-1903.

Thornton, P. K., Jones, P. G., Alagarswamy, G., \& Andresen, J. (2009). Spatial variation of crop yield response to climate change in East Africa. Global Environmental Change, 19, 54-65. doi:10.1016/j. gloenvcha. Accessed 5 August 2008.

Tilman, D., Cassman, K. G., Matson, P. A., Naylor, R., \& Polasky, S. (2002). Agricultural sustainability and intensive production practices. Nature, 418, 671-677.

Wada, N., Feng, C., \& Gulati, G. (2008). Introduction and overview. In A. Gulati \& J. Dixon (Eds.), Maize in Asia: Changing markets and incentives (pp. 28-75). New Dehi: Academic Foundation.

Ward, J. M. J., Laing, M. D., \& Cairns, A. L. P. (1997). Management practices to reduce gray leaf spot of maize. Crop Science, 37, $1257-1262$.

World Bank. (2010). Rising global interests in farmland: Can it yield sustainable and equitable benefits. Washington, DC: Agricultural and Rural Development Dept, World Bank.
Yan, J., Kandianis, C. B., Harjes, C. E., et al. (2010). Rare genetic variation at Zea mays crtRBI increases $\beta$-carotene in maize grain. Nature Genetics, 42, 322-327.

Zaidi, P. H., Manislevan, P., Srivastava, A., Yadav, P., \& Singh, R. P. (2010). Genetic analysis of water-logging tolerance in tropical maize. Maydica, 55, 17-26.

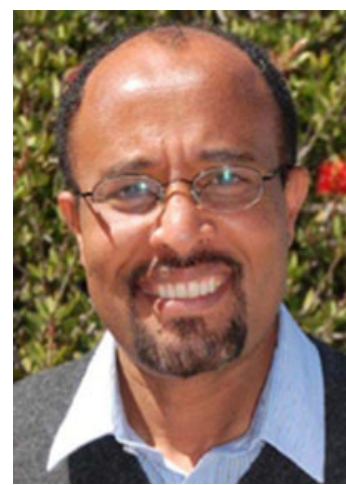

Bekele Shiferaw is Director of the Socio-Economics Program at the International Maize and Wheat Improvement Center (CIMMYT), based in Nairobi, Kenya. Previously, he worked for over 8 years as regional program leader and senior economist in Africa and South Asia with the International Crops Research Institute for the Semi Arid Tropics (ICRISAT). His research interests cover the role of institutions and policies for sustainable intensification of production, adoption and impact of agricultural and resource management research, development strategies and poverty dynamics, analysis of market relations and value chains, policy and institutional innovations for remedying market failures and adaptation to and mitigation of climate change in agriculture. He has published over 40 scientific papers in peer-reviewed international journals and books. He received his $\mathrm{PhD}$ degree in Development and Resource Economics in 1998 from the Department of Economics and Resource Management, Agricultural University of Norway.

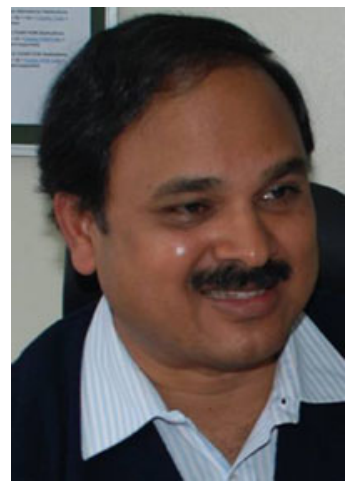

Boddupalli Prasanna is Director of the Global Maize Program at CIMMYT, based in Nairobi, Kenya. He received his $\mathrm{PhD}$ degree from the Indian Agricultural Research Institute (IARI), New Delhi, in 1991. Before joining CIMMYT he worked as a maize Geneticist at IARI and led several Network Projects on molecular breeding, gene pyramiding, quality protein maize, biofortification, functional genomics and allele mining, and phenotypic and molecular characterization of maize landraces. He also served as Team Leader for India under the Asian Maize Biotechnology Network (AMBIONET) during 1998-2005, and as National Fellow of the Indian Council of Agricultural Research (ICAR) during 2005-2010. A Fellow of the National Academy of Agricultural Sciences (India), he guided the research programs of several MSc and $\mathrm{PhD}$ students, and published more than 95 research articles and book chapters in peer-reviewed journals and 
books. He served as a member of several important policy-making bodies in India, including biosafety and biotechnology issues.

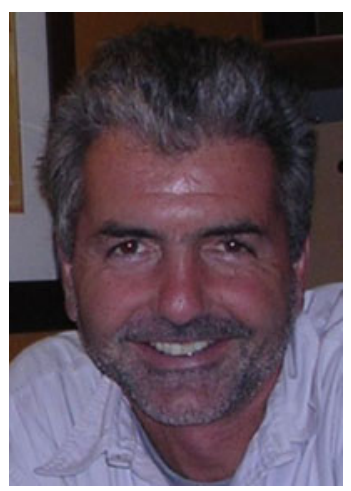

Jon Hellin works at the International Maize and Wheat Improvement Center (CIMMYT) in Mexico. He has 20 years' research and rural development experience from Latin America, South Asia and East Africa. He received his $\mathrm{BA}$ and $\mathrm{MSc}$ degrees from the University of Oxford, and his $\mathrm{PhD}$ from Oxford Brookes University. After completing a cross-disciplinary $\mathrm{PhD}$ on smallholder land management in Central America, his research has focused on farmers' livelihood security and access to markets. He has authored two books and over 25 articles in peer-reviewed international journals.

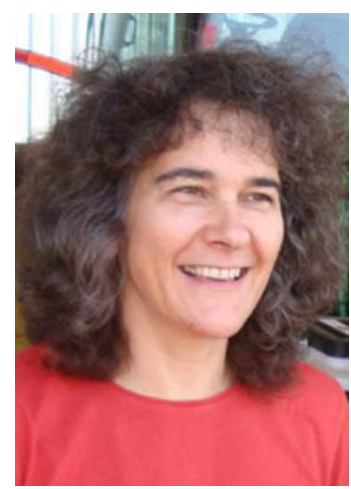

Marianne Bänziger is CIMMYT's Deputy Director General for Research and Partnerships. The International Maize and Wheat Improvement Center, known by its Spanish acronym, CIMMYT (www.cimmyt.org), is an international, not-for-profit research and training organization. With partners in over 100 countries, the center applies science to increase food security, improve the productivity and profitability of maize and wheat farming systems, and sustain natural resources in the developing world. As a crop physiologist with a $\mathrm{PhD}$ from the Swiss Federal Institute of Technology ETH in Zurich (1992), Marianne Bänziger's disciplinary expertise is in maize research targeted at stress environments. She has published over 40 articles and book chapters in peer-reviewed international journals and books, and contributed significantly to the development of drought tolerant maize varieties in Africa. 